\title{
Jak rozporządzenie Bruksela I bis rozstrzyga o jurysdykcji w sporach z międzynarodowej gwarancji ubezpieczeniowej, czyli o pojęciu sprawy ubezpieczeniowej
}

\begin{abstract}
The article presents the issue of the jurisdiction of a civil court in the light of the provisions of the EU Brussels I bis Regulation in relation to a matter in the field of insurance guarantee. This was presented against the background of qualification considerations of the insurance case and delimitation of the norms of the EU Brussels I bis Regulation in relation to disputes under the insurance contract from reinsurance disputes (in the strict sense and the so-called retrocession). At the same time, reasons were given for excluding social security from this scope. Because in practice (and in theoretical approaches) there are discrepancies as to the scope of the subject application of the standards in relation to individual insurance activities, one of the objectives of this study is to indicate that such nterpretation possibility which such a gap will remove, because it is even be harmful to the certainty of turnover, if it would appear in relation to such fundamental concepts as jurisdiction in international insurance disputes and jurisdiction in domestic disputes. Consequently, basically based on an autonomous interpretation and in the alternative: lex fori the possibility of refusing to apply the standards of section 3 of EU Regulation No. 1215/2012 to disputes in the field of insurance guarantee. An appropriate analysis of national law was also carried out, indicating the need for coherence

a) Dr hab., r.pr., Katedra Prawa Cywilnego i Prawa Międzynarodowego Prywatnego, Wydział Prawa i Administracji Uniwersytetu Kardynała Stefana Wyszyńskiego w Warszawie; członek Project Group on a Restatement of European Insurance Contract Law; członek Project Group on a Reinsurance Contract Law.
\end{abstract}


between EU and internal law standards in the area of qualifying disputes arising from the insurance guarantee.

Keywords: jurisdiction, insurance guarantee, insurance contract, Regulation (EU) No 1215/2012, Act on Insurance and Reinsurance Activity

\section{Wprowadzenie}

Spory z zakresu ubezpieczeń gospodarczych są najczęściej przedstawiane z perspektywy wzajemnych praw i obowiązków stron umowy ubezpieczenia, ewentualnie problematyki jej wykonywania bądź (co najbardziej popularne) stricte dochodzenia roszczeń z tego tytułu. Dla praktyki ubezpieczeniowej jednak nie mniej istotnym zagadnieniem, chociaż niewątpliwie jednostkowo rzadziej występującym, jest kwalifikacja sporów, których podstawę materialnoprawną stanowi stosunek gwarancji ubezpieczeniowej (scil. umowa gwarancji ubezpieczeniowej). Jest to szczególnie ważne w odniesieniu do obrotu międzynarodowego, ale także ma niebagatelne znaczenie $\mathrm{w}$ obrocie wewnętrznym, gdyż $\mathrm{w}$ obu tych płaszczyznach stosunków cywilnoprawnych gwarancja, w tym gwarancja ubezpieczeniowa, jest coraz bardziej popularna.

Należy podkreślić, że stanem pożądanym, także w polskim prawodawstwie, byłaby sytuacja, w której normy prawa materialnego sa spójne $\mathrm{z}$ rozwiązaniami obowiązującymi $\mathrm{w}$ procedurze cywilnej $\mathrm{w}$ odniesieniu do problematyki ubezpieczeń prywatnych, zwanych w polskiej tradycji gospodarczymi ${ }^{1}$. W konsekwencji, jeżeli są ku temu podstawy, to powinnościa jest w drodze wykładni norm zarówno międzynarodowego, jak i krajowego prawa ubezpieczeń gospodarczych taką koherencję utrzymywać. Ponieważ w praktyce (i w ujęciach teoretycznych) można spotkać rozbieżności co do zakresu przedmiotowego zastosowania norm w odniesieniu do poszczególnych czynności ubezpieczeniowych, jednym z celów niniejszego opracowania jest wskazanie, jaki jest zakres przedmiotowy pojęcia sprawy ubezpieczeniowej w rozporządzeniu Parlamentu Europejskiego i Rady (UE) nr 1215/2012 z dnia 12 grudnia 2012 r. w sprawie jurysdykcji i uznawania orzeczeń sądowych oraz ich wykonywania $\mathrm{w}$ sprawach cywilnych i handlowych ${ }^{2}$ [dalej: rozporządzenie Brukse-

${ }^{1}$ Co jest zresztą określeniem anachronicznym, szerzej D. Fuch s: Interes ubezpieczeniowy w europejskim projekcie PEICL $w$ świetle kodeksowej regulacji umowy ubezpieczenia. W: Księga pamiatkowa Profesora Andrzeja Kidyby. Warszawa [w druku].

${ }^{2}$ Rozporządzenie Parlamentu Europejskiego i Rady (UE) nr 1215/2012 z dnia 12 grudnia 2012 r. w sprawie jurysdykcji i uznawania orzeczeń sądowych oraz ich wy- 
la I bis, a także rozporządzenie 1215/2012]. Jest to nie tylko problem odpowiedniej kwalifikacji sporu z zakresu gwarancji ubezpieczeniowej, lecz także rozróżnienia sprawy z zakresu ubezpieczeń prywatnych od sprawy z zabezpieczenia społecznego czy też rozróżnienia sporu z umowy ubezpieczenia (bezpośredniego) od sprawy zawisłej przed sądem krajowym z tytułu reasekuracji sensu stricto, czy też reasekuracji dalszej, czyli tzw. retrocesji (por. pkt 3 niniejszego artykułu). W ślad za tym idą poglądy doktryny prawa ubezpieczeniowego, gdzie, w zależności od przyjętych przesłanek przez ich przedstawicieli, odmienne zgoła konsekwencje powoduje wykładnia obowiązujących norm także w prawie materialnym danego państwa członkowskiego UE.

Szczególnie jest to widoczne, gdy weźmie się pod uwagę postępujace umiędzynarodowienie polskiego rynku ubezpieczeniowego, gdzie coraz częściej są kreowane stosunki prawne z elementem obcym. Właśnie z tego powodu w opracowaniu podkreśla się (zob. pkt 5) znaczenie ujednolicenia prawa polskiego wewnętrznego (merytorycznego) z prawem europejskim, także w zakresie regulacji gwarancji ubezpieczeniowej, zarówno na płaszczyźnie prawa materialnego, jak i międzynarodowego procesowego (w ujęciu kolizyjnym takie wattpliwości natury zasadniczej nie powstaja $)^{3}$. Jest to nie tyle postulat potrzebny ze względu na treść norm, ile $\mathrm{z}$ uwagi na ich występująca $\mathrm{w}$ doktrynie odmienna interpretację, mimo że wykładnia dosłowna regulacji (jak też wykładnia autonomiczna dokonywana wedle przeważającej koncepcji interpretacji norm prawa międzynarodowego) nie powoduje takich rozbieżności.

Spotykanym w obrocie gospodarczym (w odniesieniu do ubezpieczeń prywatnych) interesujacym przykładem jest kwestia jurysdykcji $\mathrm{w}$ sporach rozstrzyganych na podstawie rozporządzenia Bruksela I bis, a w dalszej konsekwencji - problematyka jurysdykcji sądowej w sporach ubezpieczeniowych na podstawie tego aktu unijnego, którymi sa przecież także spory powstające $\mathrm{w}$ związku $\mathrm{z}$ udzieleniem gwarancji przez ubezpieczyciela ${ }^{4}$.

Wypada w związku z tym podkreślić, że in statu praesenti „rozczłonkowanie" w znaczeniu proceduralnym jest szczególnie zauważalne w przypadku porównania rozwiązań prawa unijnego odnoszacych się do jurysdykcji $\mathrm{z}$ analogicznymi $\mathrm{w}$ swej istocie normami odnoszącymi

konywania w sprawach cywilnych i handlowych (wersja przekształcona). Dz.Urz. UE L nr 351/1 z dnia 20.12.2012.

${ }^{3}$ Por. szeroko na ten temat M. Kropka: Kolizyjnoprawna regulacja umowy ubezpieczenia $w$ rozporzadzeniu Rzym I. Katowice 2010, passim.

${ }^{4}$ Por. odnośnie do poprzedniego, analogicznego stanu prawnego, zob. D. Fuchs: Ubezpieczenia w Unii Europejskiej [Materiał powielony, Studia podyplomowe WPiA Uniwersytetu Ślaskiego w Katowicach 2011]. 
się do miejscowej właściwości sądowej w razie sporów o charakterze wewnętrznym, rozstrzyganych na podstawie rodzimego prawa cywilnego, przy czym w specyfice polskiej zawartych zasadniczo w aktach publicznego prawa ubezpieczeniowego.

Można zatem postawić tezę, że występująca tego typu dyspersja nie służy uczestnikom rynku ubezpieczeniowego, zarówno krajowego, jak i unijnego, a już z pewnościa statuuje element niepewności po stronie podmiotów, które in concreto wdają się z ubezpieczycielem w spór sądo$\mathrm{wy}^{5}$. Dla właściwego zakwalifikowania danej czynności ubezpieczeniowej jako podległej odpowiedniej normie rozporządzenia Bruksela I bis, a tym bardziej dla prawidłowego rozróżnienia cywilnej sprawy ubezpieczeniowej (do czego gwarancję ubezpieczeniowa prima facie można zaliczyć) od sprawy z zakresu ubezpieczenia społecznego, potrzebne jest przywołanie ratio legis tego aktu prawa unijnego.

\section{Koncepcja regulacji rozporządzenia UR Bruksela I bis}

Warto przypomnieć, że już w projekcie rozporządzenia 44/2001 (ostatecznie tzw. Bruksela I) przygotowanego przez Komisję w 1999 r. podkreślono, że zasadniczą przesłanka podjęcia wysiłków legislacyjnych jest art. 2 TUE, który wyznaczył Unii Europejskiej w ramach posiadanych środków instytucjonalnych zadanie ciagłego rozwijania w ramach Unii strefy wolności, bezpieczeństwa i sprawiedliwości ${ }^{6}$. Zarazem, zdaniem projektodawcy unijnego, właśnie efektywna współpraca między państwami członkowskimi w dziedzinie sądowego prawa cywilnego jest gwarantem stabilizacji swobód traktatowych. Jednak nie następowała ona adekwatnie do oczekiwań (przynajmniej do czasu rozpoczęcia prac nad projektem rozporządzenia 44/2001), co spowodowało podjęcie przez Radę inicjatywy prac nad nowelizacją swych „poprzedniczek”, tzw. kon-

${ }^{5}$ Poprzedni stan prawny por. D. Fuchs: Wtaściwość miejscowa sqdu polskiego w przypadku sporów z gwarancji ubezpieczeniowej. „Monitor Prawniczy” 2012, nr 11, s. 582 i n.; szczegóły Idem: Jurysdykcja sqdowa w zakresie ubezpieczeń gospodarczych wedtug rozporzqdzenia Rady (WE) nr 44/2001 z dnia 22 grudnia 2000 r. w sprawie jurysdykcji $i$ uznawania orzeczeń sqdowych oraz ich wykonywania $w$ sprawach cywilnych $i$ handlowych. W: A. Brodecka-Chamera et al.: Prawo ubezpieczeń gospodarczych. Komentarz. T. 2. Warszawa 2010, s. 53 i n.

${ }^{6}$ Proposal for a Council Regulation (EC) on jurisdiction and the recognition and enforcement of judgments in civil and commercial matters. COM/99/0348 final. Dz.Urz. WE C nr 376 E, s. 1. 
wencji brukselskiej ${ }^{7}$ oraz lugańskiej (tzn. Lugano I) ${ }^{8}$. Należy podkreślić, że tak jak „następcą” rozporządzenia 44/2001 jest rozporządzenie Bruksela I bis, tak pierwotna konwencja lugańska (Lugano I) została zastapiona przez tzw. konwencję Lugano II $^{9}$, która w zakresie relewantnym dla ubezpieczeń prywatnych zawiera (jak jej poprzedniczka) rozwiązania analogiczne do prawodawstwa $\mathrm{UE}^{10}$.

Zarazem należy wskazać, że fundamentalnym celem rozporządzenia 1215/2012, zwanego rozporządzeniem Bruksela I bis (podobnie jak w przypadku jego poprzednika - rozporządzenia Bruksela I, czyli rozporządzenia UE 44/2001), jest dalszy postęp w znaczeniu rozszerzenia zastosowania podmiotowego i przedmiotowego, a także w zakresie ujednolicenia przepisów prawa prywatnego międzynarodowego w odniesieniu do jurysdykcji oraz wykonalności orzeczeń w sprawach cywilnych i handlowych ${ }^{11}$.

Niebagatelna przesłankę takiego ujednolicenia norm w skali europejskiej stanowi również konieczność dostosowania się legislatora unijnego w zakresie jurysdykcji sądowej do nowych środków technicznych wykorzystywanych w handlu międzynarodowym, co staje się szczególnie istotne dla ochrony interesów konsumentów w trakcie postępowania sadowego. Istotne znaczenie ma możliwość wykorzystania norm rozporządzenia Bruksela I bis z uwzględnieniem wymogów, jakie stawia przed uczestnikami obrotu gospodarczego i prawnego stan pandemii światowej z powodu rozprzestrzeniania się choroby COVID-19, wywoływanej przez koronawirusa SARS_CoV-2, ogłoszonej w I kwartale 2020 r. z wykorzystaniem współczesnych środków komunikacji, co zarówno generuje możliwość powstania sporów z tego tytułu (np. w zakresie elektronicznych usług finansowych), jak też pozwala, już z wykorzystaniem lex fori, przeprowadzać cywilne postępowania sądowe pomiędzy podmiotami pochodzącymi z różnych państw członkowskich UE za pomocą mediów elektronicznych oraz utrwalania dźwięku i obrazu.

Należy także wskazać, że w preambule rozporządzenia 1215/2012 podkreślono, że z uwzględnieniem zasady subsydiarności i proporcjo-

${ }^{7}$ Konwencja o jurysdykcji oraz uznawaniu i wykonywaniu orzeczeń w sprawach cywilnych i handlowych. Dz.Urz. WE C nr 27, s. 1.

${ }^{8}$ Konwencja o jurysdykcji i wykonywaniu orzeczeń sądowych w sprawach cywilnych i handlowych, sporządzona w Lugano dnia 16.09.1988 r. Dz.U. 2000, poz. 132.

${ }^{9}$ Konwencja o jurysdykcji i uznawaniu oraz wykonywaniu orzeczeń sądowych w sprawach cywilnych i handlowych. Dz.Urz. UE L nr 147, s. 5.

${ }^{10}$ Uwagi do rozporządzenia Bruksela I bis należy także odnosić do konwencji Lugano II, chyba że inaczej zaznaczono w tekście artykułu.

${ }_{11}$ Szeroko nt. potrzeby reformy rozporządzenia 44/201 i jej efektów A. Frąckowiak-Adamska: Europejska przestrzeń sqdowa - rozważania na tle projektu reformy rozporzadzenia Bruksela I. „Europejski Przegląd Sądowy” 2012/5/16-23. LEX [Dostęp: 4.04.2020 r.]. 
nalności, „(p)onieważ cel niniejszego rozporządzenia nie może zostać osiągnięty w wystarczającym stopniu przez państwa członkowskie, natomiast możliwe jest jego lepsze osiagnięcie na poziomie Unii, Unia może przyjąć środki zgodne z zasadą pomocniczości określoną w art. 5 Traktatu o Unii Europejskiej (TUE). Zgodnie z zasadą proporcjonalności określona we wspomnianym artykule, niniejsze rozporzadzenie nie wykracza poza to, co jest niezbędne do osiągnięcia tego celu". W związku z tym celem twórców było osiągnięcie za pomocą tego aktu minimalnego, ale zarazem niezbędnego efektu harmonizacji przepisów postępowania cywilnego (motyw 39 preambuły) ${ }^{12}$. Właśnie ze względu na gwarancję osiągnięcia zamierzonego stopnia harmonizacji Rada zdecydowała się po raz kolejny w rozporządzeniu 1215/2012 (poprzednio ten efekt chciano osiągnać dzięki rozporządzeniu 44/2001), aby swym zakresem przedmiotowym gwarantować jednolitość praktyki orzeczniczej w Unii Europejskiej. „Celem zagwarantowania swobodnego przepływu orzeczeń w sprawach cywilnych i handlowych niezbędnym i stosownym jest, aby przepisy o jurysdykcji oraz uznawaniu i wykonywaniu orzeczeń zostały określone w drodze aktu unijnego, który będzie wiążący i bezpośrednio stosowany"13.

Jednak należy podkreślić, co stanowi o istotnym (w sensie praktycznym) ograniczeniu podmiotowym (a zarazem przestrzennym), że mimo zamierzeń projektodawców rozporządzenia Bruksela I bis nie udało się doprowadzić do rozszerzenia zakresu podmiotowego stosowania norm jurysdykcyjnych rozporządzenia 44/2001 o podmioty z państw trzecich jako pozwane. Zrealizowano te zamierzenie jedynie w stosunku do spraw konsumenckich i pracowniczych ${ }^{14}$. A rebours, w pozostałym zakresie trzeba korzystać z przepisów dotyczących jurysdykcji międzynarodowej, zawartych, w przypadku prawa polskiego, w Kodeksie postępowania cywilnego, a mających zastosowanie do spraw z zakresu ubezpieczeń

12 Por. motyw nr 39 preambuły rozporządzenia 1215/2012; podobnie w odniesieniu do skutków wejścia w życie traktatu amsterdamskiego zob. M.A. Dau ses: Jednolite prawo cywilne w Europie. „Przegląd Prawa Handlowego” 2003, 6, s. 13; szerzej: D. Fuch s: Jurysdykcja sqdów powszechnych w zakresie ubezpieczeń gospodarczych zgodnie z rozporzqdzeniem $n r$ 1215/2012 (tzw. Bruksela I bis) z uwzględnieniem konwencji Lugano II. W: Kontrakty na rynku ubezpieczeń. Red. D. Fuchs, K. Malinowska, D. Maśniak. Warszawa [w druku].

${ }_{13}$ Motyw nr 6 preambuły rozporządzenia 1215/2012; szeroko nt. zmian w stosunku do rozporządzenia 44/2001 oraz zakresu podmiotowego B. Trocha: Uwagi na tle częściowego rozszerzenia zakresu podmiotowego rozporzqdzenia Bruksela I bis na pozwanych z państw trzecich. „Polski Proces Cywilny” 2013, 2, s. 194-212. LEX [Dostęp: 4.04.2020 r.].

${ }^{14}$ Por. B. Trocha: Jest wreszcie nowe rozporzadzenie Bruksela I bis, http://www. codozasady.pl/jest-wreszcie-nowe-rozporzadzenie-bruksela-i-bis/ [Dostęp: 4.05.2018 r.]. 
prywatnych. Wówczas niezbędne jest sięgnięcie do art. $1103^{5} \S 1$ k.p.c. ${ }^{15}$ W takiej sytuacji „(s)prawy ze stosunku ubezpieczenia przeciwko ubezpieczycielowi należą do jurysdykcji krajowej także wtedy, gdy":

a) powód ma miejsce zamieszkania ${ }^{16} \mathrm{w}$ Rzeczypospolitej Polskiej lub

b) istnieje jurysdykcja krajowa w sprawie przeciwko ubezpieczycielowi głównemu, a pozwany ubezpieczyciel jest współubezpieczycielem (koasekuratorem) lub

c) zdarzenie wywołujące szkodę nastąpiło w Rzeczypospolitej Polskiej, a sprawa dotyczy ubezpieczenia odpowiedzialności cywilnej, ubezpieczenia nieruchomości albo ubezpieczenia nieruchomości i ruchomości, gdy powstała na nich szkoda wynikła z jednego zdarzenia.

Należy podkreślić, że zarazem (w sporach określonych powyżej) ubezpieczyciel jest traktowany jako mający miejsce zamieszkania albo siedzibę w Rzeczypospolitej Polskiej, jeżeli ma zakład lub oddział w Rzeczypospolitej Polskiej, a sprawa wynikła z działalności tego zakładu lub oddziału.

$\mathrm{Na}$ tym tle nasuwają się dwie uwagi. Po pierwsze, ze względu na przyjętą terminologię $\mathrm{w}$ prawie międzynarodowym, miejsce zamieszkania ubezpieczyciela utożsamia się z jego siedzibą, co analogicznie jest rozwiązane w rozporządzeniu Bruksela I bis.

Po drugie, w przypadku łącznika lokalizującego jurysdykcję w pkt. c powyżej przywołanego artykułu k.p.c. nawiązano także do rozwiązania powszechnie przyjętego $\mathrm{w}$ ubezpieczeniach $\mathrm{OC}$, a więc triggera (tzw. zapadki czasowej) loss occurence, którego przydatność jest oczywista również dla ubezpieczeń mienia (scil. ruchomości lub nieruchomości). Także i to rozwiązanie ustawodawcy polskiego koresponduje dokładnie z rozwiązaniami przyjętymi w rozporządzeniu unijnym, by powołać się $\mathrm{w}$ tym miejscu na treść art. $12^{17}$. Przyjęcie takiej konstrukcji przez polskiego ustawodawcę należy ze wszech miar zaaprobować.

${ }_{15}$ Ustawa z dnia 17 listopada 1964 r. — Kodeks postępowania cywilnego. T.j. Dz.U. 2019, poz. 1460 ze zm.

${ }^{16}$ Co, oczywiście, odnosi się także do siedziby powoda będącego jednostką organizacyjną (osobą prawną albo nie, np. ułomną osobą prawną).

${ }_{17}$ „W odniesieniu do ubezpieczenia odpowiedzialności cywilnej lub ubezpieczenia nieruchomości ubezpieczyciel może być ponadto pozwany przed sąd miejsca, gdzie nastapiło zdarzenie wywołujące szkodę. Tę samą zasadę stosuje się, jeżeli ruchomości i nieruchomości objęte są tą samą umową ubezpieczenia, a powstała na nich szkoda wynika z tego samego zdarzenia". 


\section{Specyfika ubezpieczeń międzynarodowych}

Na marginesie należy zaznaczyć, że nie rzutuje to oczywiście w żadnym stopniu na prawo właściwe, przy czym w przypadku niektórych ubezpieczeniowych stosunków prawnych należy zwrócić uwagę na prawo konwencyjne. I tak, gdy sprawa dotyczy roszczeń wynikających z wypad$\mathrm{ku}$ komunikacyjnego, zgodnie z art. 3 Konwencji z dnia 4 maja $1971 \mathrm{r}$. o prawie właściwym dla wypadków drogowych ${ }^{18}$, prawem właściwym jest prawo wewnętrzne państwa, w którym nastąił wypadek. Jednak dla gwarancji ubezpieczeniowej takich rozwiązań konwencyjnych w zakresie prawa właściwego dotychczas brak. Oczywiście, pozostaje kwestia stosowania prawa unijnego w zakresie poszukiwania prawa właściwego, jednak charakterystyka tego problemu wykracza poza ramy niniejszego opracowania ${ }^{19}$. Powodem zasadniczym takiego stanu rzeczy (scil. rozproszenia regulacji) jest intensywny rozwój ubezpieczeń prywatnych, głównie w wymiarze międzynarodowym.

Należy jeszcze raz podkreślić, że ubezpieczenia sa ściśle powiązane $\mathrm{z}$ handlem międzynarodowym, co z prawnego i prawniczego punktu widzenia powoduje określone konsekwencje. Przede wszystkim istnieje tendencja do harmonizacji prawa ubezpieczeń gospodarczych, czego najbardziej doniosłym przykładem jest właśnie prawodawstwo Unii Europejskiej. Jednak, co potwierdza analiza zakresu podmiotowego i przedmiotowego regulacji wtórnego prawa unijnego, stan harmonizacji został osiągnięty za pomoca obowiązujących źródeł prawa w odniesieniu do dość szczegółowych i wybranych obszarów regulacyjnych w porównaniu z kompleksowością regulacji ubezpieczeń gospodarczych, stanowiącą ich cechę charakterystyczna w prawodawstwach poszczególnych państw członkowskich Unii Europejskiej. Szczególny tego przykład stanowią w terminologii prawa i praktyki Unii Europejskiej tzw. ubezpieczenia cross-border, polegajace zasadniczo na świadczeniu usługi ubezpieczeniowej przez ubezpieczyciela

18 Dz.U. 2003, nr 63, poz. 585.

19 Szerzej, częściowo na tle poprzedniego stanu prawnego: D. Fuchs: Wtaściwość sqdu i właściwość prawa w europejskich ubezpieczeniach gospodarczych. „Prawo Asekuracyjne" 2008, nr 2, s. 49-65, a także w kontekście poprzedniego stanu prawnego Idem: Swoboda świadczenia ustug $w$ świetle nowego prawa ubezpieczeniowego. W: Finansowe narzędzia zarzqdzania zakładem ubezpieczeń. Red. T. Sangowski. Warszawa 2005, s. 77-92; Idem: Ubezpieczenia gospodarcze w świetle Konwencji rzymskiej i projektu Rozporzadzenia „Rzym II”. „Forum Dyskusyjne Ubezpieczeń i Funduszy Emerytalnych” 2005, z. 5, s. 25-41, a także Idem: Charakter prawny polisy ubezpieczeniowej $w$ prawie polskim a przedmiotowy zakres zastosowania Konwencji wiedeńskiej o umowach międzynarodowej sprzedaży towarów z 1980 roku. Przyczynek do wyktadni norm międzynarodowego prawa handlowego. „Rozprawy Ubezpieczeniowe” 2009 (6), nr 1, s. 19-26. 
z siedziba w innym państwie (home country) niż państwo miejsca spełnienia świadczenia (host country), czyli polegające na korzystaniu w zakresie ubezpieczeń gospodarczych z unijnej swobody świadczenia usług. Należy mieć równocześnie świadomość, że prawo stanowione przez powołane do tego organy danego państwa (państw) lub organizacji międzynarodowych zawiera jedynie częściowa regulację, dlatego też praktyka obrotu wielokrotnie odwołuje się do reguł i zwyczajów handlowych, takich jak np.:

1. INCOTERMS - International Commercial Terms - Międzynarodowe Terminy Handlowe; terminy określające przede wszystkim prawa i obowiązki stron umowy sprzedaży lub dostawy towaru, w tym również gestię ubezpieczeniowa.

2. Institute Cargo Clauses - Klauzule Instytutowe Ubezpieczycieli Londyńskich; powszechne $\mathrm{w}$ ubezpieczeniu ładunku $\mathrm{w}$ transporcie (tzw. ubezpieczenie cargo $\mathrm{w}$ ruchu międzynarodowym) - które sa specyficzne dla międzynarodowego obrotu cywilnego (handlowego, lex mercatoria) ${ }^{20}$.

Można przyjaćc, że cechą właściwą dla współczesnych ubezpieczeń jest standaryzacja warunków ubezpieczenia, będąca w ogromnym stopniu skutkiem umiędzynarodowienia praktyki zawierania i wykonywania umów ubezpieczenia, a także wpływu anglosaskiego rynku ubezpieczeń ${ }^{21}$. Prowadzi to jednak także do dyspersji normatywnej i, co za tym idzie, pojęciowej w ubezpieczeniach prywatnych (z powodu swobody w kształtowaniu treści wzorców ubezpieczeniowych przez ubezpieczycieli), co wywołuje (jako reakcję na taki stan) naturalny proces harmonizacji bądź wręcz ujednolicenia regulacji odnoszących się do poszczególnych aspektów międzynarodowego rynku ubezpieczeniowego, szczególnie europejskiego. Należy zatem przyjać, że współcześnie immanentną cechą ubezpieczeń gospodarczych (szczególnie europejskich; unijnych) jest ich umiędzynarodowienie, co najlepiej oddaje pojęcie transgraniczności, rozumiane jako powiązanie stosunku ubezpieczenia $\mathrm{z}$ więcej niż jednym obszarem prawnym ${ }^{22}$. Z tego też powodu na gruncie doświadczeń wynikających z międzynarodowego prawa ubezpieczeniowego możemy wyróżnić trojakie rozumienie tejże transgraniczności ${ }^{23}$. Taki właśnie proces już występuje, a koncentruje się

${ }^{20}$ Por. D. Fuchs: Umowa ubezpieczenia. Materiaty dla IV edycji Podyplomowego Studium Prawa Cywilnego dla Sędziów Sadów Powszechnych w roku 2008/2009. Warszawa 2008, s. 1 i n.; szerzej: Idem: Jurysdykcja sqdów powszechnych w zakresie ubezpieczeń gospodarczych zgodnie z rozporzqdzeniem $\mathrm{nr}$ 1215/2012 (tzw. Bruksela I bis)...

${ }^{21}$ Szczegóły: W. Janusz: Rynek światowy - na przyktadzie Lloyd’s. W: Kontrakty na rynku ubezpieczeń. Red. D. Fuchs, K. Malinowska, D. Maśniak...

${ }^{22}$ Charakterystyka zob. E. Kow alewski: Ubezpieczenia transgraniczne - aspekty prawne. „Gazeta Ubezpieczeniowa” z dnia 10.01.2006 r.

${ }^{23}$ Szerzej por. D. Fuchs, w: Kontrakty na rynku ubezpieczeń. Red. D. Fuchs, K. Malinowska, D. Maśniak... 
na następujących aspektach umiędzynarodowienia (transgraniczności) ubezpieczeń:

1) kolizyjnoprawnym ${ }^{24}$,

2) materialnoprawnym ${ }^{25}$,

3) jurysdykcyjnym wraz z wykonalnością orzeczeń sądowych ${ }^{26}$.

$\mathrm{Na}$ płaszczyźnie materialnoprawnej niewątpliwie interesujący przykład stanowi tutaj efekt prac tzw. Project Group on a Restatement of European Insurance Contract Law (PEICL - Project on European Insurance Contract Law) w zakresie ustalenia regulacji umowy ubezpieczenia, gdyż maja one charakter projektu instrumentu opcjonalnego prawa unijnego ${ }^{27}$. Kolejnym przykładem odnoszacym się do prób tworzenia prawa jednolitego międzynarodowego, ale już w skali ponadeuropejskiej — światowej (w zakresie reasekuracji ${ }^{28}$ i retrocesji), jest PRICL — Project on Reinsurance Contract Law. Project of Reinsurance Contract Law z założenia i na podstawie koincydencji z PEICL ma postać tzw. soft law ${ }^{29}$, które może być wybrane przez strony danej umowy reasekuracji jako prawo właściwe (a w zasadzie prawidłowym modus operandi będzie materialnoprawne wskazanie prawa), i może być w konsekwencji uznane w razie ewentualnego sporu rozstrzyganego przez sąd powszechny albo - na podstawie stosownej klauzuli arbitrażowej - przez sąd polubowny (scil. arbitrażowy) jako podstawa materialnoprawna takiego rozstrzygnięcia. Takie rozwiązanie wydaje się szczególnie atrakcyjne w razie orzekania przez skład arbitrażowy według zasady słuszności

${ }^{24}$ Szerzej zob. E. Kow alewski: Problematyka kolizyjnego prawa ubezpieczeniowego. „Państwo i Prawo” 2005, z. 2, s. 21 i n., a także: K. Policha, A. Wnęk: Prawo prywatne międzynarodowe. Zasady wyboru prawa właściwego dla dużych ryzyk ubezpieczeniowych. Zagadnienia praktyczne. „Prawo Asekuracyjne” 2011, 3, s. 6 oraz M. Pilich: Statut umów ubezpieczenia wedtug rozporzadzenia Rzym I. W: Europejskie prawo procesowe cywilne i kolizyjne. Red. P. Grzegorczyk, K. Weitz. Warszawa 2012, s. 313 i n.

${ }_{25}$ D. Fuchs: Nowelizacja kodeksu cywilnego $w$ zakresie wybranych przepisów ogólnych o umowie ubezpieczenia $w$ świetle przepisów ogólnych o umowie ubezpieczenia $w$ świetle prac Project Group on a Restatement European Insurance Contract Law. „Wiadomości Ubezpieczeniowe" 2007, 7-8, s. 32 i n.

${ }^{26}$ Szerzej na temat tego podziału zob. D. Fuchs: Transgraniczna umowa. „Miesięcznik Ubezpieczeniowy" 2006, 6, s. 32-33.

${ }^{27}$ Omówienie projektu: D. Fuchs: PEICL jako materialnoprawny projekt europejskiego instrumentu opcjonalnego $w$ zakresie prawa jednolitego o umowie ubezpieczenia. W: Kontrakty na rynku ubezpieczeń. Red. D. Fuchs, K. Malinowska, D. Maśniak...

${ }^{28} \mathrm{Na}$ temat istoty reasekuracji por. D. Fuchs: Komentarz do art. 820 k.c. W: Kontrakty na rynku ubezpieczeń. Red. D. Fuchs, K. Malinowska, D. Maśniak... i tam przywołana literatura.

${ }_{29}$ Por. także M. Wandt, J. Gal: Solvency II is unexpected. Indirect regulation of the Reinsurance Contract, http://www.icir.de/fileadmin/Documents/Policy_Platform/ 180426_ICIR_JB_PP_Solvency_II_Unexpected.pdf [Dostęp: 31.03 .2020 r.]. 
(scil. ex aequo et bono), co jest powszechnie dopuszczone w regulaminach sądów arbitrażowych na świecie, zasadniczo za uprzednią akceptacją takiego procedowania przez strony sporu. Nie jest zarazem celem autorów projektu tworzenie umowy reasekuracji od nowa; jest to raczej koncepcja ujednolicenia występujących już $\mathrm{w}$ praktyce i prawodawstwie rozwiazań i stworzenia z nich systematycznego wykładu praw i obowiazków na wzór amerykańskich Restatements, a przede wszystkim PEICL ${ }^{30}$.

\section{Pojęcie sprawy z zakresu ubezpieczenia (prywatnego) w rozumieniu rozporządzenia Bruksela I bis}

Już w tytulaturze sekcji 3. prawodawca wspólnotowy przyjął, że zakres przedmiotowy tej jednostki redakcyjnej rozporządzenia Bruksela I bis będzie się odnosił do jurysdykcji w sprawach dotyczaccych ubezpieczeń (por. uwagi dalsze), a wobec tego kluczowe jest prawidłowe rozumienie pojęcia ubezpieczenia, w konsekwencji zaś - spraw z zakresu ubezpieczeń. Zarazem użycie przez prawodawcę europejskiego, co oczywiste, pojęcia jurysdykcji oznacza także, że kwestia fundamentalną w stosowaniu norm rozporządzenia w odniesieniu do właściwości sądowej jest stwierdzenie charakteru międzynarodowego danego powództwa ${ }^{31}$. Dopiero wówczas po spełnieniu tej przesłanki i po stwierdzeniu, że zrealizowano także przesłanki z art. 4-6 rozporządzenia, które określają zakres podmiotowy przepisów jurysdykcyjnych, mamy do czynienia z zastosowaniem norm rozporządzenia. W przeciwnym wypadku mają zastosowanie przepisy jurysdykcyjne prawa wewnętrznego (zob. uwagi powyższe) ${ }^{32}$.

${ }^{30}$ Por. D. Fuchs: Ujednolicenie kontraktowego prawa reasekuracyjnego $w$ skali międzynarodowej ,in statu nascendi” - PRICL (Project of Reinsurance Contract Law). „Wiadomości Ubezpieczeniowe” 2019, nr 1, s. 23-36, a także por. Zakładka na stronie www.dariuszfuchs.pl oraz https://www.unidroit.org/work-in-progress/525-reinsu rance-contracts/2124-study-l-formulation-of-principles-of-reinsurance-contracts [Dostęp: 31.03.2020 r.].

${ }^{31}$ Por. K. Weitz: Przedmiotowy zakres zastosowania Konwencji lugańskiej. „Kwartalnik Prawa Prywatnego" 2000, z. 2, s. 430—433, a także Idem: Projektowane zmiany rozporzqdzenia $n r$ 44/2001. W: Europejskie prawo procesowe cywilne $i$ kolizyjne. Red. P. Grzegorczyk, K. Weitz..., s. 27 i n.

${ }^{32}$ Por. Kodeks postępowania cywilnego. Komentarz. T. 5: Postępowanie egzekucyjne. Red. T. Ereciński. Wyd. 5. LEX [Dostęp: 4.04.2020 r.], natomiast w odniesieniu do konwencji Lugano I zob. S. Naderhofer: New Federal Law on Jurisdiction. Harmonisation of Local Jurisdiction in Civil Matters in Domestic Context, www.bscc.co.uk/taxnews/ tax0300.html [Dostęp: 31.03.2020 r.]. 


\subsection{Kwestia zabezpieczenia społecznego}

Analizując zakres przedmiotowy rozporządzenia Bruksela I bis (czyli pojęcia sprawy cywilnej, w kontekście zakresu przedmiotowego sekcji 3. - sporów z ubezpieczeń), należy pamiętać, że zarówno w angielskiej (social security), francuskiej (la sécurité sociale), jak i niemieckiej (die soziale Sicherheit) wersji językowej wyłączono sprawy z zakresu zabezpieczenia społecznego, co polski tekst oddaje za pomoca zawężonego (niestety) pojęcia ubezpieczeń społecznych ${ }^{33}$. Należy podkreślić, że o ile pojęcie ubezpieczeń społecznych zawiera się w semantyce zabezpieczenia społecznego, o tyle te pojęcia nie sa żadna miara synonimiczne. I tak doktryna francuska pojęciem zabezpieczenia społecznego sensu largo obejmuje także ubezpieczenia prywatne, co jednak nie jest konstatacją wiążaca na potrzeby analizy zakresu zastosowania norm rozporządzenia Bruksela I bis. Tym samym należy przyjąć pilna potrzebę korekty oficjalnej polskiej wersji językowej (ten mankament występował zresztą już wcześniej w treści rozporządzenia 44/2001, jak też $\mathrm{w}$ tłumaczeniach konwencji brukselskiej i Lugano I, a jest wciąż obecny w konwencji Lugano II) w tym zakresie, co skłania jeszcze raz do wyrażonego na wstępie postulatu, że stosowanie zasadniczo poprawnej wykładni językowej, popartej wykładnią autonomiczna z niezbędnym wspomożeniem lex fori (zob. uwagi dalsze), tylko pozytywnie przyczyniłoby się do jednolitości stosowania przepisów rozporządzenia Bruksela I bis zarówno w orzecznictwie sądów polskich, jak i innych państw UE. W literaturze powszechnie uznaje się za powód tego wyłaczenia przynależność w większości państw członkowskich norm regulujących zabezpieczenie społeczne do prawa publicznego oraz różnorodność w tym względzie regulacji zawartych w poszczególnych porządkach prawnych. Dodatkowo należy zauważyć, że zasadniczo kwestia ta nie stanowiła do niedawna szczególnego przedmiotu orzecznictwa TSUE (wcześniej: Europejskiego Trybunału Sprawiedliwości - ETS) oraz sadów krajowych ${ }^{34}$ państw członkowskich ${ }^{35}$.

Chociaż, co należy podkreślić, nie zawarto $\mathrm{w}$ tekście definicji materii należącej do zabezpieczenia społecznego, w praktyce orzeczniczej nawiązuje się zasadniczo do zakresu zastosowania tzw. rozporządzeń

${ }^{33}$ Nie podlega jednak dyskusji, że pojęcie „zabezpieczenie społeczne” jest szersze niż pojęcie „ubezpieczenie społeczne”; analogicznie por. D. Fuchs: Działalność ubezpieczeniowa w świetle Konwencji brukselskiej - Lugano o jurysdykcji i wykonywaniu orzeczeń w sprawach cywilnych $i$ gospodarczych. „Rejent” 1999, nr 3, s. 64.

${ }_{34}$ Por. K. Weitz: Przedmiotowy zakres zastosowania..., s. 460-461.

${ }_{35}$ Por. C. Quigley: Zakres zastosowania konwencji brukselskiej i konwencji lugańskiej. „Kwartalnik Prawa Prywatnego” 1999, z. 4, s. 703. 
Rady koordynujacych systemy zabezpieczenia społecznego państw członkowskich Unii Europejskiej (rozporządzenie Parlamentu Europejskiego i Rady (WE) nr 883/2004 z dnia 29 kwietnia 2004 r. w sprawie koordynacji systemów zabezpieczenia społecznego ${ }^{36}$ ) oraz do konwencji MOP nr 102/1952, nadając autonomiczny charakter takiej kwalifikacji ${ }^{37}$.

Potwierdza to obowiązujace stanowisko ETS, przede wszystkim w orzeczeniu wstępnym wydanym w sprawie Gemeente Steenbergen v. Luc Baten na skutek zapytania skierowanego przez sąd belgijski w związku z postępowaniem sądowym wszczętym przez Gemeente Steenbergen (holenderska jednostkę samorządu terytorialnego) przeciwko osobie zamieszkałej w Belgii ${ }^{38}$. W tym wypadku Europejski Trybunał Sprawiedliwości podkreślił, że pojęcie spraw cywilnych, o których mowa w art. 1 konwencji, musi być wykładane autonomicznie ${ }^{39}$. Odwołano się tu także do istniejącej wcześniej linii orzeczniczej ${ }^{40}$.

Tym samym prawodawca unijny w rozporzadzeniu Bruksela I bis nie pozostawił wątpliwości, że akt ten nie ma zastosowania do spraw z zakresu zabezpieczenia społecznego, co oznacza jednocześnie, że takie sprawy nie są objęte jurysdykcją sądową wyznaczana na podstawie odrębnych przepisów określających jurysdykcję szczególną w odniesieniu do ubezpieczeń prywatnych. Ponieważ rozporządzenie Bruksela I bis nie ma zastosowania do spraw z zakresu zabezpieczenia społecznego, tym bardziej upadają wszelkie watpliwości co do niestosowania do takich spraw norm sekcji 3., poświęconej co do zasady jurysdykcji dla spraw z ubezpieczeń (prywatnych).

${ }^{36}$ Rozporządzenie Parlamentu Europejskiego i Rady (WE) nr 883/2004 z dnia 29.04.2004 r. w sprawie koordynacji systemów zabezpieczenia społecznego. Dz.Urz. UE L nr 166, s. 1 ze zm.

${ }^{37}$ Por. częściowo na tle poprzedniego stanu prawnego, co nie utraciło aktualności obecnie, T. Ereciński, J. Ciszewski: Międzynarodowe postępowanie cywilne. Warszawa 2000, s. 34; K. Weitz: Przedmiotowy zakres zastosowania..., s. 460-462; szerzej, wraz z literatura przedmiotu, zob. D. Fuch s: Zarys prawa ubezpieczeń socjalnych w Unii Europejskiej. Katowice 1997, s. 22-33; Idem: Normy kolizyjne w ubezpieczeniach. Próba porównania (na przyktadzie rozwiazań europejskich). W: II i III filar ubezpieczeń emerytalnych. Demograficzne i społeczne uwarunkowania ubezpieczeń. Red. A. Rączaszek. Katowice 1999, s. 161-165.

${ }^{38}$ Wyrok TS z dnia 14.11.2002 r., C-271/00: Gemeente Steenbergen v. Luc Baten. EU:C:2002:656.

${ }^{39}$ Rangę wykładni autonomicznej przy zastosowaniu rozporządzenia nr 1215/2012 podkreślają: J. Gołaczyński, M. Zalisko: Jurysdykcja krajowa szczególna w sprawach dotyczacych czynu niedozwolonego lub czynu podobnego do niedozwolonego $w$ rozporzqdzeniu nr 1215/2012. „Europejski Przegląd Sądowy” 2019, nr 4, s. 24-25, gdzie podają także relewantne orzeczenia w tym względzie.

${ }^{40}$ Zilustrowano zarówno orzeczeniem LTU przeciwko Eurocontrol, jak też wyr. TS z dnia 16.12.1980 r., C-814/79: Rüffer. EU:C:1980:291. 
Warto podkreślić, że powodem takiej szczególnej jurysdykcji dla spraw ubezpieczeniowych była przede wszystkim chęć stworzenia reguł jurysdykcyjnych chroniących stronę kontraktu, która zazwyczaj akceptuje zaproponowane (i z góry przygotowane $\mathrm{w}$ celu faworyzowania pozycji proponenta wzorca) warunki (scil. ogólne i szczegółowe warunki ubezpieczenia), przez druga - tutaj ubezpieczyciela. Tym samym brak balansu pomiędzy potencjalnymi kontrahentami, przy praktycznej występującej co do zasady przewadze organizacyjnej, merytorycznej i częstokroć finansowoprawnej ubezpieczyciela, skłonił prawodawcę europejskiego do wprowadzenia, wzorem wielu rozwiązań krajowych, systemu szczególnych norm, których zadaniem jest ułatwienie dostępu do wymiaru sprawiedliwości w ramach UE dla ubezpieczajacych, ubezpieczonych czy też innych osób uprawnionych do świadczeń ubezpieczeniowych (np. beneficjentów w umowach ubezpieczeń na życie).

Tożsamy powód spowodował wyodrębnienie norm jurysdykcyjnych w odniesieniu do umów konsumenckich. Odrębna, niemniej ważną przyczyna, chociaż rzadziej podkreślaną w literaturze, było istotne zróżnicowanie relewantnych przepisów w poszczególnych państwach członkowskich $^{41}$.

W ten sposób dział 3. Jurysdykcja w sprawach dotyczacych ubezpieczenia odnosi się jedynie do ubezpieczeń prywatnych, a nie takich, którym można przydać przymiot publicznych, czy szerzej spraw z zakresu zabezpieczenia społecznego. Chociaż przepisy rozporządzenia Bruksela I bis nie zawierają definicji tego pojęcia (taka definicja $\mathrm{z}$ powodu chociażby różnorodności systemów zabezpieczenia społecznego w Europie, system Beveridge'a versus system bismarkowski, byłaby praktycznie niemożliwa do przyjęcia), to nie ulega watpliwości, podobnie jak w przypadku zagadnienia kwalifikacji spraw z zakresu „ubezpieczenia społecznego”, że jego wykładnia nie powinna być dokonywana wyłącznie zgodnie z lex fori, ale winna uwzględniać przede wszystkim postulat autonomicznej interpretacji rozporządzenia ${ }^{42}$. Oczywiście pozostaje pytanie, co wchodzi w zakres przedmiotowy ubezpieczeń prywatnych, a szczegółowiej — czy spory ze wszystkich czynności ubezpieczeniowych o charakterze unijnym i transgranicznym podlegaja sekcji $3{ }^{43}$

${ }^{41}$ Por. P. Kaye: Civil Jurisdiction and Enforcement of Foreign Judgements. Abingdon 1987 , s. 806.

${ }^{42}$ Por. J. Kropholler: Europäisches Zivilprozeßrecht. Kommentar zu EuGVÜ und Lugano-Übereinkommen. Heidelberg 1996, s. 160; P. Schlosser: Europäisches Gerichtsstands- und Vollstreckungsübereinkommen mit Luganer Übereinkommen und den Haager Übereinkommen über Zustellung und Beweisaufnahme. München 1996, s. 69.

${ }_{43}$ Szerzej D. Fuchs: Jurysdykcja sqdów powszechnych $w$ zakresie ubezpieczeń gospodarczych zgodnie z rozporzadzeniem nr 1215/2012 (tzw. Bruksela I bis)... 


\subsection{Jak rozumieć pojęcie działalności ubezpieczeniowej w rozporządzeniu I bis?}

Analogicznie do powyższego w analizach dotyczących konwencji brukselskiej zwraca się uwagę na wykładnię zgodną ze „wspólnotowym rozumieniem pojęć", co jest o tyle łatwiejsze w praktyce, że konwencja brukselska stanowiła (a stanowi wciąż w odniesieniu do Danii) immanentna część acquis, co tym bardziej dotyczy rozporządzenia Bruksela I bis ${ }^{44}$. Należy jednocześnie zwrócić uwagę, że w prawie wspólnotowym występuje de lege lata brak kompleksowej definicji działalności ubezpieczeniowej (jak też umowy ubezpieczenia, poza odpowiednią normą unijnego projektu PEICL ${ }^{45}$ ), wyjąwszy katalog tzw. ryzyk ubezpieczeniowych oraz zasadę oddzielenia ubezpieczeń na życie od pozostałych ubezpieczeń, jak o tym stanowia dyrektywy ubezpieczeniowe tzw. pierwszej generacji ${ }^{46}$.

Trzeba podkreślić, że bez znaczenia dla właściwości przepisów sekcji 3. rozporządzenia Bruksela I bis jest forma organizacyjno-prawna jednej ze stron kontraktu, a w szczególności fakt, że ubezpieczycielem jest podmiot należący do danego państwa ${ }^{47}$. Jest to analogiczna koncepcja do tej, dzięki której dana sprawa uznawana jest za cywilną, a mianowicie sprawą cywilna jest ta, której powództwo oparte jest na prawie prywatnym ${ }^{48}$.

$\mathrm{W}$ polskich realiach w kontekście interpretacji spraw z zakresu ubezpieczeń nie można wykluczyć możliwości oceny zastosowania przepisów art. 8 i n. ustawy o działalności ubezpieczeniowej i reasekuracyjnej [dalej: u.d.u.r.] przez wzgląd na art. 4 u.d.u.r. ${ }^{49}$, która zawiera definicję działalności ubezpieczeniowej podobną do obowiązujących w niektórych innych państwach członkowskich Unii Europejskiej ${ }^{50}$. Wobec tego

${ }^{44}$ Por. Product Liability. European Laws and Practice. Ed. C. Hodges. London 1993, s. 124.

${ }^{45}$ Artykuł 1: 201(1) PEICL, szerzej por. D. Fuchs: PEICL jako materialnoprawny projekt europejskiego instrumentu opcjonalnego...

${ }^{46}$ Por. D. Fuchs, w: E. Kowalewski, D. Fuchs, W.W. Mogilski, M. Serwach: Prawo ubezpieczeń gospodarczych. ToruńBydgoszcz 2006.

${ }^{47}$ Zob. orzeczenie szwajcarskiego sądu federalnego Banque Bruxelles Lamber (Suisse) przeciwko Republique du Paraguay et Sezione speciale per l'assicurazione del credito all'esportazione z dnia 20.08.1998 r., www.jura.uni-sb.de.

${ }^{48}$ Interesująco ten wątek, wskazując na odmienności pomiędzy tradycją kontynentalna a Common Law, omawiają: G. Walter, S.P. Baumgarten: Recognition and Enforcement of Foreign Judgements Outside the Scope of the Brussels and Lugano Conventions. The Hague-London-Boston 2000, s. 12-14.

${ }^{49}$ Ustawa z dnia 11 września 2015 r. o działalności ubezpieczeniowej i reasekuracyjnej. T.j. Dz.U. 2018, poz. 999 ze zm.

50 Szerzej zob. D. Fuchs: Holding ubezpieczeniowy w prawodawstwie polskim oraz wspólnotowym. Zarys problematyki. W: Harmonizacja polskiego prawa gospodarczego 
uzasadniona jest interpretacja pojęcia spraw ubezpieczeniowych (scil. sprawy ubezpieczeniowej) pomocniczo oparta na prawie merytorycznym państwa członkowskiego, ale jedynie wtedy, gdy jest zgodna z celem rozporządzenia Bruksela I bis (i analogicznie jego poprzednika lub właściwych konwencji brukselskiej i obu lugańskich) oraz zasadami systemów prawnych państw $\mathrm{UE}^{51}$.

\subsection{Reasekuracja i retrocesja}

Zarówno w literaturze przedmiotu ${ }^{52}$, jak i w orzecznictwie utrwaliło się już przekonanie, że europejskie normy jurysdykcyjne odnoszące się stricte do sporów ubezpieczeniowych nie maja zastosowania do spraw, których podstawą materialnoprawną jest umowa reasekuracji lub retrocesji ${ }^{53}$.

z wymogami Unii Europejskiej. Red. B. Gnela, R. Szostak. Kraków 2001, s. 171; Idem: Znaczenie ratyfikacji przez RP Konwencji z Lugano dla wtaściwości sqdu w zakresie ubezpieczeń gospodarczych. W: Wymiar sprawiedliwości w Unii Europejskiej. VI Ogólnopolska Konferencja Prawnicza, Toruń 16-17 listopada 2000 roku. Red. C. Mik. Toruń 2001, s. 408-409, a także Idem: Komentarz do art. 805 k.c. W: Kontrakty na rynku ubezpieczeń. Red. D. Fuchs, K. Malinowska, D. Maśniak...

${ }^{51}$ Orzeczenia ETS-u: LTU v. Eurocontrol z 1976 r. oraz Gemeente Steenbergen v. Luc Baten z 2002 r.; szerzej zob. D. Fuchs: Wtaściwość sqdu i właściwość prawa..., s. 51-55; zarazem należy podkreślić nowatorskie ujęcie tematu przez K. Pacułę, zob. K. Pacuła: Kwalifikacja $w$ prawie prywatnym międzynarodowym Unii Europejskiej. Od kwalifikacji autonomicznej ku... kwalifikacji wedtug „lex fori”. Referat wygłoszony podczas konferencji nt. Aktualne problemy prawa prywatnego międzynarodowego, Toruń, 13-14 czerwca 2019 r., gdzie referent odwołał się także do tego ostatniego orzeczenia, zob. „Problemy Prawa Prywatnego Międzynarodowego” 2019, T. 25, s. 107 i n.; interesujące rozważania na ten temat prowadzi także M. Fras: Umowa ubezpieczenia grupowego. Aspekty prawne. Warszawa 2015. LEX [Dostęp: 4.04.2020 r.].

${ }^{52}$ Por.: International Contracts. Aspects of Jurisdiction, Arbitration and Private International Law. Ed. M. Koppenol-Laforce. London 1996, s. 48; P. Schlosser: Europäisches Gerichtsstands- und Vollstreckungsübereinkommen..., s. 69-70; D.J. Freeman: International Jurisdiction and the Recognition and enforcement of foreign judgements: Preaction protocol for debt claims, www.djfreeman.co.uk/pubs/l-jurisd.htm, s. 5 [Dostęp: 31.03 .2020 r.]; A. Layton: The Interpretation of the Brussels Convention by the European Court and English Courts. „Civil Law Quartely” 1992, vol. 2, s. 35—36, który powołując się na orzeczenie w sprawie New Hampshire v. Strabag Bau, wskazuje, że biorąc pod uwagę wykładnię celowościową, można postulować wyłączenie z zakresu zastosowania konwencji brukselskiej również innych umów ubezpieczenia, które sa zawierane między zakładem ubezpieczeń a np. międzynarodowym konsorcjum budowlanym, co również, jak w przypadku umowy reasekuracji, nie znajduje uzasadnienia w wykładni językowej konwencji. Wydaje się, że wypowiedzi doktryny uznają za aksjomat tezę P. Schlossera; por. D. Fuch s: Działalność ubezpieczeniowa..., s. 65, przyp. 19.

${ }_{53}$ Por. European Parliament opinion on the proposal for a Council..., s. 9. 
Dla uchwycenia specyfiki reasekuracji cenne sa konstatacje wynikające $\mathrm{z}$ orzeczeń sądów brytyjskich ${ }^{54}$. Za reprezentatywny przykład może także służyć orzeczenie w sprawie New Hampshire v. Strabag Bau AG, w którym sąd wskazał, że należy stwierdzić, iż ochronny charakter przepisów rozdziału 3. (scil. konwencji Lugano I, co jest aktualne w przypadku sekcji 3. rozporządzenia Bruksela I bis) jest zbędny w przypadku umowy reasekuracji, w której nie występuje ubezpieczony, którego interesów należy w sposób wzmożony chronić ${ }^{55}$. Odmienne wnioski w tym zakresie powodowałyby z kolei niepotrzebne zdublowanie przepisów dotyczących jurysdykcji sądu w sprawach konsumenckich ${ }^{56}$. Wprowadzenie w praktyce swoistego superfluum niewątpliwie nie służyłoby uczestnikom rynku ubezpieczeniowego. Analogicznie zasadność wyłączenia umowy reasekuracji z tego kręgu semantycznego znalazła również swoją aktualność w sprawie Group Josi Reinsurance Company Co. v. Universal General Insurance Company rozstrzyganej przez Europejski Trybunał Sprawiedliwości ${ }^{57}$. Występuje także przekonujący argument, że istotą działalności reasekuracyjnej jest dyspersja w zakresie tzw. dużych ryzyk ${ }^{58}$, co ze swej istoty wiąże się z działalnością profesjonalnie przygotowanych do zawierania odpowiednich umów ubezpieczenia zakładów ubezpieczeń, które sa zarazem równoprawnym kontrahentem dla reasekuratorów. Tym samym nie ma potrzeby angażowania prawodawcy unijnego w tworzenie czy też adaptowanie norm szczególnych, de facto ochronnych, dla jakiejkolwiek strony takiego dwustronnie kwalifikowanego stosunku prawnego.

Należy zatem przyjąć, że umowa reasekuracji tak dalece różni się od umowy ubezpieczenia, że nie ma potrzeby zamieszczać takiego wyłączenia w przepisach poświęconych właściwości sądu w odniesieniu do sporów wynikłych z umowy ubezpieczenia ${ }^{59}$. Należy także podkreślić $\mathrm{w}$ zgodzie z analizą prawnoporównawcza, że stosunek reasekuracji jest

${ }^{54}$ Zob. Agnew et al. v. Lansforsakringsbolagens AB. „The All England Law Reports" 2000, 1, s. 737. Por. C. Renfors, F. van der Velden, R. Wagner: Trzecie sprawozdanie na temat krajowego prawa precedensowego dotyczacego konwencji z Lugano, https://bip.ms.gov.pl/Data/Files/_public/bip/lugano/raporty/lugano_raport3.pdf [Dostęp: 31.03.2020 r.].

55 Zob. sędzia Potter, in: New Hampshire v. Strabag AG; por. M. Clarke: The Law of Insurance Contracts. London 1994, s. 62.

${ }_{56}$ Por. D. Fuchs: Działalność ubezpieczeniowa..., s. 65; Idem, w: Prawo o kontraktach w ubezpieczeniach. Komentarze do przepisów i wybranych wzorców umów. Red. Z. Brodecki. Zakamycze 2003, passim.

${ }^{57}$ Wyrok TS z dnia 13.07.2000 r., C-412/98, Group Josi Reinsurance Company SA v. Universal General Insurance Company (UGIC). EU:C:2000:399.

${ }^{58}$ Por. T.H. Ellis: The Single European Market and Insurance Law and Practice. London 1994, s. 65.

${ }_{59}$ Por. treść art. 820 polskiego k.c., szerzej D. Fuchs, w: Kontrakty na rynku ubezpieczeń. Red. D. Fuchs, K. Malinowska, D. Maśniak... 
prawnie relewantny jedynie pomiędzy reasekuratorem (tzw. cesjonariuszem) a ubezpieczycielem (cedentem), gdyż reasekurator tylko w stosun$\mathrm{ku}$ do swego kontrahenta odpowiada umownie, a ubezpieczajacy (lub ubezpieczony) nie ma żadnego roszczenia, nawet na wzór actio directa przy ubezpieczeniu OC, do reasekuratora ${ }^{60}$.

Podobnie Europejski Trybunał Sprawiedliwości przywołał dodatkowo wyrażona przez siebie tezę w uzasadnieniu Gerling Konzern Speziale Kreditversicherungs - AG et al. v. Administrazione del Tresoro dello Stato: ,jest oczywiste po rozważeniu przepisów tego rozdziału [3. konwencji brukselskiej, zob. sekcja 3. rozporządzenia I bis - D.F.], [...] że ich celem jest ochrona ubezpieczonego, który jest najczęściej strona kontraktu, którego postanowień nie może negocjować i który się znajduje w ekonomicznie słabszej pozycji” ${ }^{61}$. Taka sytuacja nie zachodzi ani $\mathrm{w}$ umowie reasekuracji, ani retrocesji.

Nie należy zapominać, że umowa ubezpieczenia zazwyczaj jest precyzyjnie definiowana w prawodawstwach państw członkowskich UE, co w przypadku umowy reasekuracji występuje o wiele rzadziej. Sa to umowy „koncepcyjnie różne”. „Żaden [...] ze społecznych aspektów umowy ubezpieczenia nie występuje w odniesieniu do umowy reasekuracyjnej”62. Funkcja gospodarczą umowy reasekuracji nie jest tworzenie nowych funduszy, lecz bardziej efektywne korzystanie ze środków zgromadzonych przez poszczególnych ubezpieczycieli ${ }^{63}$.

Dodatkowym, równie przekonującym, argumentem jest stwierdzenie, że prawodawca unijny, dokonując reglamentacji działalności reasekuracyjnej, przede wszystkim w celu zagwarantowania efektywnej możliwości korzystania w ramach rynku wspólnotowego z zasady swobody zakładania przedsiębiorstw i swobody świadczenia usług, oddzielnie reglamentuje sferę ubezpieczeń bezpośrednich oraz reasekuracji ${ }^{64}$. W podobnym

${ }^{60}$ Tak słusznie Z. Jęk sa: Ubezpieczenia majatku i zysku firmy. Warszawa 1999, s. 97.

${ }^{61}$ Zob. wyr. TS z dnia 14.07.1983 r., C-201/82, Gerling Konzern Speziale Kreditversicherung AG et al. v. Amministrazione del Tesoro dello Stato. EU:C:1983:217.

${ }^{62}$ Por. J. Łopuski: Umowa ubezpieczeniowa a umowa reasekuracji w orzecznictwie Europejskiego Trybunału Sprawiedliwości. W: Ubezpieczenia w gospodarce rynkowej. T. 3. Red. T. Sangowski. Bydgoszcz-Poznań 2002, s. 67, gdzie autor przytacza stanowisko Adwokata Generalnego ze sprawy Group Josi Reinsurance Company SA, a także por. interesujące rozważania odnoszące się do natury działalności ubezpieczeniowej i odpowiednio reasekuracyjnej na s. $69-73$.

${ }^{63}$ Ibidem, s. 71 (warto podkreślić, że w dużej mierze rozważania autora odnosza się do europejskich rozwiązań w zakresie jurysdykcji na podstawie przepisów konwencji brukselskiej i odpowiednio Lugano I).

${ }^{64}$ Szerzej zob. D. Fuchs, w: E. Kowalewski, D. Fuchs, W.W. Mogilski, M. Ser wach: Prawo..., s. 532 i n. oraz E. Kowalewski, D. Fuchs, M.P. Ziemiak: Implementacja dyrektywy reasekuracyjnej do polskiego porzadku prawnego. „Prawo Asekuracyjne” 
kierunku zmierza część prawodawców krajowych, chociaż nie wszyscy, bo prawodawca polski stara się ująć obie działalności, chociaż merytorycznie i redakcyjnie separując $\mathrm{w}$ jednej ustawie (u.d.u.r.). Pozostaje do rozwikłania kwestia, jak w tym ewentualnym zakresie, w kontekście zakresu przedmiotowego zastosowania sekcji 3. rozporządzenia Bruksela I bis, mieści się gwarancja ubezpieczeniowa.

\section{Casus gwarancji ubezpieczeniowej w rozporządzeniu Bruksela I bis}

Rozporządzenie Bruksela I bis (podobnie jak w przypadku sporów wynikłych ze stosunku gwarancji bankowej) nie zawiera wprost szczególnych przepisów jurysdykcyjnych dotyczących stosunku gwarancji ubezpieczeniowej, co uzasadnia prima facie (oprócz także aktualnego w kontekście regulacji „Bruksela I bis” argumentu celowościowego, powołującego się na aksjologię norm chroniących uzasadnione interesy ubezpieczającego, ubezpieczonego czy też poszkodowanego) negatywna odpowiedź na zasadnicze pytanie o możliwość zastosowania także norm sekcji dotyczącej ubezpieczeń prywatnych do spraw sądowych, których materialnoprawna podstawa sa prawa i obowiązki wynikające np. z zawartej umowy o udzielenie gwarancji ubezpieczeniowej.

Sytuacja tożsama do wyżej opisanej występuje w odniesieniu do umowy gwarancji ubezpieczeniowej. Innymi słowy, nie ulega wątpliwości, że czynność ubezpieczeniowa $\mathrm{w}$ postaci udzielenia przez ubezpieczyciela gwarancji ubezpieczeniowej mieści się $\mathrm{w}$ zakresie ubezpieczeń prywatnych oraz jest przejawem działalności ubezpieczeniowej, odmiennie niż zabezpieczenie społeczne, a analogicznie do reasekuracji wraz z retrocesja (zob. pkt 3 rozważań). To jednak nie przesądza jeszcze o szczegółowym umiejscowieniu w treści rozporządzenia Bruksela I bis jurysdykcji sporów sądowych tego rodzaju.

W ślad za powyższymi tezami, przyjętymi prima facie, na zasadzie wykładni celowościowej o wyłączeniu stosowania „ubezpieczeniowych” norm jurysdykcyjnych rozporządzenia UE Bruksela I bis (por. umowa reasekuracji lub retrocesji) w zakresie sporów z ubezpieczeń prywatnych do stosunku gwarancji ubezpieczeniowej, zasadne jest jednak bardziej szczegółowe odniesienie się do tego problemu.

2009, nr 2, a także D. Fuchs: Jurysdykcja sqdów powszechnych w zakresie ubezpieczeń gospodarczych zgodnie z rozporzadzeniem $\mathrm{nr}$ 1215/2012 (tzw. Bruksela I bis)... 
$\mathrm{Z}$ powołaniem się na refleksje zawarte w pkt. 3 niniejszego artykułu należy zadać pytanie, czy stosować szczególne przepisy jurysdykcyjne odnoszące się do ubezpieczeń także do umowy ubezpieczenia, co jest zagadnieniem dotychczas niepodkreślonym $\mathrm{w}$ orzeczeniach zapadłych w związku z konwencją lugańską i odpowiednio brukselską, a także rozporządzeniem 44/2001, a w konsekwencji rozporządzeniem 1215/2012. W związku z tym powstają wątpliwości w kontekście ewentualnego stosowania przepisów sekcji 3. rozporządzenia Bruksela I bis do sporów powstałych na podstawie zawartych umów gwarancji ubezpieczeniowej ${ }^{65}$. Jest to zabieg o tyle istotny, że pojawił się w literaturze rodzimej ciekawy pogląd o dopuszczalności takiej wykładni, jak mniema autor, w odniesieniu do stosownych europejskich norm jurysdykcyjnych ${ }^{66}$.

Koncepcyjnie ujmując tę kwestię, to gwarant będący zakładem ubezpieczeń (ubezpieczycielem) udziela beneficjentowi zabezpieczenia ziszczenia się określonego rezultatu, najczęściej wykonania umowy przez osobę trzecia - zleceniodawcę gwarancji w postaci zobowiązania do wypłaty określonej umową sumy ${ }^{67}$. Taki mechanizm konstrukcyjny występuje niezależnie od mnogości poszczególnych rodzajów gwarancji ubezpieczeniowych w obrocie gospodarczym, zarówno krajowym, jak i międzynarodowym $^{68}$. Można przyjąć (podobnie jak w przypadku gwarancji bankowych), że współcześnie najczęściej występuje gwarancja na pierwsze żądanie i nieodwołalna ${ }^{69}$. Z kolei charakteryzując umowę gwarancji ubezpieczeniowej jako jednostronnie kwalifikowana (status ubezpieczyciela) umo-

65 Szczegółowo wraz z cytowana tam literatura zob. G. Tracz: Umowa gwarancji ze szczególnym uwzględnieniem gwarancji bankowej. Kraków 1998; R. Blajer: Gwarancje bankowe $i$ ubezpieczeniowe $w$ obrocie międzynarodowym. Warszawa 1999, a także zob. B. Andrzejuk, I. Heropolitańska: Gwarancje, poręczenia, awale i akredytywy standby. Warszawa 2000; J. Pisuliński, w: Prawo bankowe. Komentarz. Red. E. Fojcik- Mastalska. Warszawa 1999.

${ }^{66}$ Por. M. Kropka: Pojęcie umowy ubezpieczenia $w$ świetle przepisów wspólnotowych dyrektyw ubezpieczeniowych. „Problemy Prawa Prywatnego Międzynarodowego" 2007, nr 1, s. 81; interesujące rozważania odnoszące się do kolizyjnych (a także prawnoporównawczych) aspektów gwarancji ubezpieczeniowej zawarto w pracy Idem: Kolizyjnoprawna regulacja umowy ubezpieczenia $w$ rozporzadzeniu Rzym I..., s. 47 i n.

${ }^{67}$ Por. G. Tracz, w: Encyklopedia prawa bankowego. Red. W. Pyzioł. Warszawa 2000, s. 225; A. Tynel, J. Funk, W. Chwalej: Międzynarodowe prawo handlowe. Red. M. Pazdan. Warszawa 2002, s. 184; szerzej D. Fuchs: Jurysdykcja sqdów powszechnych $w$ zakresie ubezpieczeń gospodarczych zgodnie z rozporzqdzeniem $\mathrm{nr}$ 1215/2012 (tzw. Bruksela I bis)...

${ }^{68}$ Przykładowe wyliczenie wraz z omówieniem L. Michalik, D. Seliga: Ubezpieczenia finansowe. W: Podstawy ubezpieczeń. T. 2: Produkty. Red. J. Monkiewicz. Warszawa 2011, s. 300-306.

${ }^{69} \mathrm{Na}$ co zwracaja słusznie uwage T. Kwieciński, J. Pokrzywniak, P. Jrus: Wstrzymanie realizacji gwarancji ubezpieczeniowej lub bankowej na podstawie postanowienia sadowego. „Wiadomości Ubezpieczeniowe” 2015, nr 2, s. 67-68. 
wę nienazwaną (co czasami jest kwestionowane ze względu na regulację publicznego prawa ubezpieczeniowego ${ }^{70}$ ), gdzie zobowiązanie gwaranta - zakładu ubezpieczeń ma charakter samoistny i abstrakcyjny ${ }^{71}$, a beneficjent jako oblat zasadniczo decyduje o przyjęciu oferty ubezpieczyciela (w trybie ofertowym, co może nastapić także w efekcie przeprowadzonych rokowań lub przetargu ${ }^{72}$ ), należy wyróżnić, zgodnie z poglądem ugruntowanym w literaturze przedmiotu ${ }^{73}$, trzy stosunki umowne.

Pierwszy z nich to zobowiązanie pomiędzy zleceniodawca gwarancji a jej beneficjentem (stosunek podstawowy). Z niego wynika kolejny stosunek, a mianowicie zobowiązanie pomiędzy zobowiązanym - zleceniodawcą gwarancji - a ubezpieczycielem, które ma postać umowy udzielenia gwarancji na rzecz beneficjenta ${ }^{74}$, określanej również mianem umowy o gwarancję ubezpieczeniowa ${ }^{75}$. Pomiędzy ubezpieczycielem a beneficjentem gwarancji nawiązuje się z kolei trzeci stosunek umowny umowa gwarancji ubezpieczeniowej ${ }^{76}$.

Konsekwentnie należy założyć, że spory wynikłe z zawartej umowy o gwarancję ubezpieczeniową należy wykluczyć spośród takich, które mieszczą się w zakresie przedmiotowym sekcji 3. rozporządzenia Bruksela I bis, z następujących zasadniczych powodów. Przede wszystkim jest to umowa o świadczenie usług, niebędąca jednocześnie umowa ubezpieczenia, chociaż $\mathrm{w}$ odniesieniu do tego stwierdzenia można by kontrargumentować, że wykazuje na tyle ścisły związek z działalnościa ubezpieczeniową, że może sensu legis mieścić się w zakresie spraw ubezpieczeniowych z sekcji 3. Należy zauważyć jednak, że istnieją istotne argumenty za poglądem przeciwnym. Przede wszystkim, uwzględniając zarówno wykładnię autonomiczna, jak i wyniki zgodnej z nią analizy prawnoporównawczej, nie można uznać umowy o gwarancję ubezpiecze-

${ }^{70} \mathrm{~W}$ polskich realiach, przez wzgląd na wymienienie przez prawodawce gwarancji ubezpieczeniowej jako dopuszczalnej czynności, w Załączniku (Podziat ryzyka wedtug działów, grup i rodzajów ubezpieczeń) do ustawy z dnia 11 września 2015 r. o działalności ubezpieczeniowej i reasekuracyjnej. T.j. Dz.U. 2019, poz. 381.

${ }^{71}$ Zob. także V. Bödeker: Staatliche Exportkreditversicherungssysteme. BerlinNew York 1992, s. 19.

${ }^{72}$ Co w rodzimych realiach występuje relatywnie często w związku z zastosowaniem ustawy z dnia 29.01.2004 r. — Prawo zamówień publicznych. Dz.U. 2019, poz. 1843 ze zm.

${ }^{73}$ Por. J. Kukiełka: Ubezpieczenie kredytu. Warszawa 1994, s. 24; Idem: Ubezpieczyciel jako gwarant. „Prawo Asekuracyjne” 1995, 3, s. 34; chociaż zauważalne są inne poglądy na tę materię, zestawienie w E. Kowalewski: Prawo ubezpieczeń gospodarczych. Bydgoszcz-Torun 2002, s. 346-347.

${ }^{74}$ Por. R. Blajer: Gwarancje bankowe i ubezpieczeniowe..., s. 17 i 21.

${ }^{75}$ J. Kukiełka: Ubezpieczyciel..., s. 34-35.

${ }^{76}$ Por. Ubezpieczenia finansowe $i$ gwarancje ubezpieczeniowe. Red. R. Holly. Warszawa 2003, s. 80. 
niową za kontrakt, w którym występuje ubezpieczający, ubezpieczony lub beneficjent (uposażony) w znaczeniu, o którym mowa w przepisach sekcji 3., chociażby przez wzgląd na art. 10 rozporządzenia Bruksela I bis ${ }^{77}$. W odróżnieniu od umowy ubezpieczenia, przyjmuje się powszechnie, że jest to stosunek prawny jednostronnie zobowiązujący i niewzajemny. W dalszej kolejności trzeba podkreślić, że o ile w umowie ubezpieczenia udzielona ochrona jest świadczeniem wzajemnym za składkę, o tyle w umowie o gwarancję ubezpieczeniową odpowiedzialność ubezpieczyciela nie jest od tego bezwzględnie uzależniona (sprzęgnięta wzajemnie) ${ }^{78}$. $\mathrm{W}$ stosunku gwarancyjnym nie występuje także popularny w umowie ubezpieczenia paradygmat zakazu wzbogacenia ${ }^{79}$.

Jednocześnie, co stanowi drugą przyczynę wyłączenia, istnieje jeszcze jedna obiekcja co do kwalifikowania takiej umowy jako umowy mieszczacej się w zakresie zastosowania przepisów rozporządzenia Bruksela I bis dotyczacych spraw ubezpieczeniowych. Jest nia, podobnie jak w przypadku reasekuracji, status kontrahenta, który będąc z zasady profesjonalnym przedsiębiorca, zawiera umowę $\mathrm{z}$ ubezpieczycielem nie $\mathrm{w}$ celu zapewnienia sobie ochrony ubezpieczeniowej na wzór umowy ubezpieczenia (w której powstający stosunek prawny jest częstokroć bardziej skomplikowany faktycznie i prawnie ex definitione od stosunku gwarancji ubezpieczeniowej; dlatego też można wywodzić konieczność ochrony klienta ubezpieczyciela). W przypadku umowy o udzielenie gwarancji taka konieczność nie występuje, a funkcja zakładu ubezpieczeń nie różni się zasadniczo od funkcji banku, który udziela w analogicznych stanach faktycznych gwarancji. Dlatego też ewentualne odwoływanie się przez ubezpieczycieli w praktyce, w razie udzielenia gwarancji ubezpieczeniowej do treści ogólnych warunków ubezpieczenia, należy uznać za całkowicie nieskuteczne, chociaż nic nie stoi na przeszkodzie skonstruowania przez ubezpieczyciela np. ogólnych warunków gwarancji ubezpieczeniowej ${ }^{80}$. Wynika to także $\mathrm{z}$ nieakcesoryjnego charakteru stosunku gwarancyjnego ${ }^{81}$. Można również $\mathrm{w}$ tym abstrakcyjnym charakterze gwarancji ubezpieczeniowej doszukiwać się criterium divisionis dla odseparowania tego stosunku od umowy ubezpieczenia, która powszechnie uznawana jest za kauzalna ${ }^{82}$.

${ }^{77} \mathrm{~W}$ prawie polskim por. J. Kukiełka: Gwarancje z punktu widzenia zakładu ubezpieczeń. „Przegląd Ubezpieczeń Społecznych i Gospodarczych” 1998, nr 4, s. 30.

${ }^{78}$ L. Michalik, D. Seliga: Ubezpieczenia finansowe..., s. 306.

${ }^{79} \mathrm{Na}$ te i inne różnice słusznie zwraca uwagę E. Kowalewski: Prawo ubezpieczeń gospodarczych..., s. 351-352.

${ }^{80}$ Słusznie J. Kukiełka, D. Poniewierka: Ubezpieczenia finansowe. BydgoszczWarszawa 2003, s. 92-93.

${ }^{81}$ Na co zwraca uwagę R. Blajer: Gwarancje bankowe i ubezpieczeniowe..., s. 21.

${ }^{82}$ Zamiast wielu E. Kowalewski, w: E. Kowalewski, D. Fuchs, W.W. Mogilski, M. Serwach: Prawo..., s. 234. 
O ile dla stosunku ubezpieczeniowego ma znaczenie np. należyte wykonanie zobowiązania przez ubezpieczonego na podstawie umowy ubezpieczenia OC, o tyle w gwarancji bez znaczenia co do zasady pozostanie dla obowiązku wykonania przez ubezpieczyciela jako gwaranta fakt spełnienia stosownych świadczeń umownych przez zleceniodawcę gwarancji beneficjentowi w ramach tzw. stosunku podstawowego ${ }^{83}$.

Przyjmując powyższe uzasadnienie, ani konwencja brukselska, ani konwencje lugańskie (i odpowiednio rozporządzenia 44/2001 oraz 1215/2012) nie zawierają szczególnych przepisów jurysdykcyjnych, co uzasadnia negatywną odpowiedź na pytanie o możliwość zastosowania norm sekcji 3. do spraw sądowych, których materialnoprawna podstawa sa prawa i obowiązki wynikające z zawartej umowy o udzielenie gwarancji ubezpieczeniowej. Różnice występujące zarówno w praktyce, jak i będące tego pochodnymi regulacje poszczególnych państw członkowskich wskazuja, że w tym zakresie sekcję 3., obejmująca prima facie normami szczególnymi jurysdykcję dotyczącą spraw z zakresu ubezpieczeń do umowy o gwarancję ubezpieczeniowa, należy wykluczyć.

Analogiczna sytuacja występuje w odniesieniu do umowy gwarancji ubezpieczeniowej. Również w tym zakresie nie można wskazać na orzeczenia Europejskiego Trybunału Sprawiedliwości ani na dotychczas wydane główne precedensy sądowe państw członkowskich, ale istnieja orzeczenia zapadłe w odniesieniu do sporów powstałych w związku z gwarancją bankową. W jednym z takich orzeczeń austriackiego Sądu Najwyższego $^{84}$ wyraźnie podkreślono umowny charakter gwarancji bankowej ${ }^{85}$, a w związku z tym stwierdzono właściwość w tym zakresie normy art. 5 ust. 1 konwencji lugańskiej, która stwierdza in capita, że „osoba, która ma miejsce zamieszkania na terytorium jednego z Umawiajacych się Państw, może być pozwana w innym Umawiającym się Państwie, jeżeli przedmiotem postępowania jest umowa lub roszczenia wynikające z umowy - przed sąd miejsca, gdzie zobowiązanie zostało wykonane albo miało być wykonane" (co jest odpowiednikiem art. 5 pkt 1 rozporządzenia 44/2001 i art. 5 pkt 1 rozporządzenia Bruksela I bis). Stąd można wywodzić wniosek, że wobec podobieństw umowy gwarancji ubezpieczeniowej

${ }^{83}$ Szerzej Ubezpieczenia finansowe $i$ gwarancje ubezpieczeniowe. Red. R. Holly..., s. 8182 .

${ }^{84}$ Por. Oberster Gerichtshof Nr. 11 z dnia 9.09.1997 r.; por. H. Bull, G. Musger, F. Pocar: Drugie sprawozdanie na temat krajowego prawa precedensowego dotyczacego Konwencji z Lugano, http://bip.ms.gov.pl/Data/Files/_public/bip/lugano/raporty/lugano_ raport2.pdf.

${ }^{85}$ Chociaż są w literaturze zgłaszane poglądy odmienne, które argumentują jednostronny charakter tej czynności prawnej, por. J. Pisuliński, w: Prawo bankowe. Komentarz. Red. E. Fojcik-Mastalska..., s. 134-135. 
i bankowej ${ }^{86}$ również w przypadku tej pierwszej będzie właściwa norma „ogólna” rozporządzenia unijnego jako lex generalis dla właściwości sądowej w odniesieniu do sporów wynikających z kontraktów.

Może się jednocześnie wydawać, że nie jest to pogląd przesądzający, chociażby z uwagi na fakt, że sekcja 3. rozdziału II rozporządzenia 1215/2012, zatytułowana Jurysdykcja $w$ sprawach dotyczacych ubezpieczenia, nie ma swojego odpowiednika w odniesieniu do umów bankowych, co przy podkreślonej ogólnej przesłance wyodrębnienia w treści konwencji przypadków właściwości szczególnej co do ubezpieczeń i konsumentów (sekcja 4. ${ }^{87}$, jaka jest ochrona słabszej organizacyjnie i ekonomicznie strony kontraktu, może zrodzić postulat regulacji w odniesieniu do usług bankowych, co jest jednak mało prawdopodobne. Jednak ze względu na „ochronny” charakter norm sekcji poświęconej ubezpieczeniom gospodarczym rozporządzenia Bruksela I bis taki argument należy uznać za chybiony, gdyż nie ma racjonalnych przyczyn, aby chronić interesy zleceniodawcy gwarancji czy też gwaranta, tak jak prawo unijne czyni to w odniesieniu do ubezpieczonego czy poszkodowanego przez normy jurysdykcyjne ${ }^{88}$. Tutaj per analogiam właściwe jest ponowne przywołanie poglądów sformułowanych na tle stosunku umownego reasekuracji i retrocesji, a przytoczonych powyżej.

Tym samym można zasadnie przyjąć wniosek, że sekcja 3. rozporzadzenia Bruksela I bis, odnosząca się formalnie do jurysdykcji w zakresie ubezpieczeń, zasadniczo, z poszanowaniem ratio regulationis użytej przez prawodawcę unijnego liczby mnogiej, w rzeczywistości dotyczy spraw z umów ubezpieczeń, a nie wszystkich czynności ubezpieczeniowych (zob. np. wyłaczenie reasekuracji i retrocesji), jakie dopuszcza obrót prawny państw członkowskich UE. Warto po raz kolejny podkreślić, że nie wyklucza to spraw z zakresu koasekuracji, gdyż ten stosunek prawny powszechnie jest utożsamiany z umową ubezpieczenia (scil. bezpośredniego), a nie np. reasekuracja czy gwarancją ubezpieczeniowa (do czego podobieństw relewantnych nie ma w ogóle).

${ }^{86}$ Nie można jednak zapominać o istotnych różnicach, zob. R. Blajer: Gwarancje bankowe $i$ ubezpieczeniowe..., s. 19—22; zob. analiza prawnoporównawcza instytucji gwarancji G. Tracz: Umowa gwarancji..., s. 45.

${ }^{87}$ Por. J. Łopuski: Konwencja lugańska $i$ jej znaczenie dla praktyki ubezpieczeniowej. „Prawo Asekuracyjne” 2001, nr 2, s. 9; K. Flaga-Gieruszyńska: Konwencja o jurysdykcji krajowej $i$ wykonalności orzeczeń $w$ sprawach cywilnych $i$ handlowych wybrane zagadnienia. „Rejent” 2000, nr 1, s. 76.

${ }^{88}$ Szerzej w poprzednim stanie prawnym D. Fuchs, w: A. Brodecka-Chamera et al.: Prawo ubezpieczeń gospodarczych. Komentarz. T. 2..., s. 73-77; pogląd odmienny prezentuje M. Kropka: Pojęcie umowy ubezpieczenia $w$ świetle przepisów wspólnotowych..., s. 81-82. 
Dodatkowo można podkreślić istotne różnice między umową ubezpieczenia a umowa gwarancji ubezpieczeniowej ${ }^{89}$, także wynikających z regulacji ubezpieczeniowej lex fori na przykładzie prawa polskiego.

W przypadku umowy ubezpieczenia ubezpieczyciel zapewnia ochronę ubezpieczonemu na wypadek ryzyka wystąienia skutków zdarzeń losowych, w zamian za co ubezpieczający zobowiązuje się do zapłaty składki (por. art. 805 k.c. w zw. z art. 4 u.d.u.r.). Wysokość świadczenia finansowego, do którego zobowiązuje się zakład ubezpieczeń w ubezpieczeniu mienia lub OC będącego następstwem powstałej szkody, jest zasadniczo ograniczona jej wartością (istotne odmienności występują w tym zakresie dla ubezpieczeń osobowych, regulowanych art. 828-834 k.c., co nie zmienia jednak konkluzji autora, gdyż gwarancji ubezpieczeniowej, jako czynności w zakresie ubezpieczeń innych niż ubezpieczenia na życie, nie należy przyrównywać np. do umowy ubezpieczenia na życie ${ }^{90}$ ). Nie ma też podstawy prawnej nawet do per analogiam stosowania przepisów Tytułu XXVII Księgi III Kodeksu cywilnego do stosunku gwarancji ubezpieczeniowej z powodu konstrukcyjnych różnic obu stosunków prawnych. W umowie gwarancji samoistna odpowiedzialność ubezpieczyciela jest uzależniona od roszczenia zgłoszonego przez beneficjenta, który składki nie płaci i nie otrzymuje w związku z tym ochrony ubezpieczeniowej. Tym samym nie ma znaczenia, co do zasady, fakt ani wysokość poniesionej przez beneficjenta szkody. Jest to konkluzja zasadniczo spójna na tle prawnoporównawczym ${ }^{91}$. Z tego też względu obecnie wciąż nie ma podstaw do przyjęcia poglądu (jak pod rządami rozporządzenia 44/2001), że zasięgiem norm sekcji 3. rozporządzenia Bruksela I bis należy objąć stosunek gwarancji ubezpieczeniowej, także przy pomocniczym wykorzystaniu wykładni lex fori, w hipotetycznym stanie rozstrzygania sprawy przez sąd polski ${ }^{92}$. Nie zmienia to oczywiście faktu, że do ewentualnych zagadnień dotyczących właściwości sądowej przy sporach cywilnych z tytułu gwarancji ubezpieczeniowej zastosowanie mają ogólne normy dotyczące właściwości oraz wykonalności zapadłych orzeczeń z tego tytułu.

${ }^{89} \mathrm{~W}$ odniesieniu do prawa polskiego por. S. Mazurkiewicz: Działalność gwarancyjna zakładów ubezpieczeń. „Wiadomości Ubezpieczeniowe” 1999, 1—2, s. 38 i n.

${ }_{90}$ Por. Załącznik (Podział ryzyka wedtug działów, grup i rodzajów ubezpieczeń) do ustawy z dnia 11 września 2015 r. o działalności ubezpieczeniowej i reasekuracyjnej. T.j. Dz.U. 2019, poz. 381.

${ }_{91}$ Por. konkluzja E. Kowalewskiego. E. Kowalewski: Prawo ubezpieczeń gospodarczych..., s. 352.

${ }_{92}$ Por. szerzej D. Fuchs, w: A. Brodecka-Chamera et al.: Prawo ubezpieczeń gospodarczych. Komentarz. T. 2..., s. 77; odmiennie w literaturze polskiej proponuje M. Kropka: Pojęcie umowy ubezpieczenia $w$ świetle przepisów wspólnotowych..., szczególnie s. 81-82. 


\section{Właściwość sądowa w sporach z gwarancji w polskim prawie ubezpieczeniowym jako przykład rozwiązania krajowego UE}

Warto podkreślić, że polski system prawny odznacza się pewna, różnie ocenianą (krytycznie przez autora), specyfiką lokalizacji normy dotyczącej właściwości miejscowej przy sporach ze stosunku ubezpieczenia. Dodatkowo owa specyfika ma już utrwaloną legislacyjnie tradycję - w poprzednim stanie prawnym relewantną regulację dotyczącą właściwości sądowej w sprawach ubezpieczeniowych nie w Kodeksie postępowania cywilnego (gdzie znajduja się przepisy natury ogólnej) ${ }^{93}$, lecz w ówczesnej ustawie z dnia 22 maja 2003 r. o działalności ubezpieczeniowej. Tutaj wprowadzono szczegółową właściwość sądu ze względu na miejsce zamieszkania lub siedzibę odpowiednio: ubezpieczającego, osoby ubezpieczonej, uposażonego lub osoby uprawnionej do świadczenia na podstawie umowy ubezpieczenia (art. 9) ${ }^{94}$ oraz notabene (co szczególnie istotne dla problematyki dochodzenia roszczeń w związku z zawartymi umowami ubezpieczenia komunikacyjnego OC) w art. 20 ust. 1 u.u.o. Należy podkreślić, że takie rozwiązanie już wówczas powodowało, że ta szczególną właściwością sądową nie były objęte spory z zakresu gwarancji ubezpieczeniowej, gdyż nie było żadnych podstaw normatywnych, aby utożsamiać czy to beneficjenta $\mathrm{z}$ uprawnionym $\mathrm{z}$ umowy ubezpieczenia, czy to strony umowy o udzielenie gwarancji ze stronami umowy ubezpieczenia. Tym samym spory $\mathrm{z}$ gwarancji ubezpieczeniowej podlegały przepisom Kodeksu postępowania cywilnego o właściwości miejscowej. Dodatkowo na tym tle sformułowane zostały argumenty przemawiające za takim rozumowaniem. Przywołany przepis historycznie brzmiał następujaco: „Powództwo o roszczenia wynikajace z umów ubezpieczenia można wytoczyć albo według przepisów o właściwości ogólnej, albo przed sąd właściwy dla miejsca zamieszkania lub siedziby ubezpieczającego, ubezpieczonego, uposażonego lub uprawnionego z umowy ubezpieczenia".

Powyższe skłaniało do wniosku, że spory wynikłe z zawartej umowy o gwarancję ubezpieczeniowa (scil. o zlecenie gwarancji ubezpieczeniowej) można wykluczyć spośród tych, które mieściły się w zakresie art. 9

${ }_{93}$ Por. w kontekście konwencji lugańskiej (Lugano I) cenne uwagi J. Łopu ski: Konwencja o jurysdykcji $i$ wykonywaniu orzeczen sqdowych $w$ sprawach cywilnych $i$ handlowych (Lugano 1988) z uwzględnieniem orzecznictwa Europejskiego Trybunału Sprawiedliwości. Bydgoszcz 2001, s. 37-40.

${ }_{94}$ Ustawa z dnia 22 maja 2003 r. o działalności ubezpieczeniowej. Dz.U. 2003, nr 124, poz. 1151 ze zm. 
ustawy o działalności ubezpieczeniowej [dalej: ustawa ubezpieczeniowa ${ }^{95}$. Nie można było także uznać umowy o gwarancję ubezpieczeniowa za kontrakt, w którym występuje ubezpieczający, ubezpieczony lub beneficjent (uposażony) w znaczeniu, o jakim mowa w art. 805-834 k.c. ${ }^{96}$

Powyższa przyczyna do pewnego stopnia stanowiła analogię $\mathrm{w}$ stosunku do obowiązującego de lege lata rozwiązania $\mathrm{w}$ odniesieniu do umowy reasekuracji. Zgodnie z art. 820 k.c., do umowy ubezpieczenia pośredniego (reasekuracji) nie stosuje się przepisów o umowie ubezpieczenia z Kodeksu cywilnego. Oczywiście nie oznaczało to braku możliwości stosowania do umowy reasekuracji przepisów ówczesnej ustawy ubezpieczeniowej, szczególnie wobec faktu najbardziej obszernej nowelizacji tego aktu, licząc od daty wejścia w życie ${ }^{97}$.

Podobnie w przypadku umowy o gwarancję ubezpieczeniowa trzeba pamiętać, że przez wzgląd na treść poprzednio obowiązującego art. 3 ust. 1 ustawy ubezpieczeniowej oraz treść Załącznika do niej Podziat ryzyka wedtug działów grup i rodzajów ubezpieczeń (dział II pkt 15) należało bez watpliwości dopuścić stosowanie relewantnych norm tej ustawy do umowy kreującej stosunek gwarancji ubezpieczeniowej.

Pomimo formułowanych zastrzeżeń co do zasadności takiego rozwiązania, a przede wszystkim umiejscowienia normy proceduralnej w ustawie z zakresu publicznego prawa ubezpieczeniowego, jakim jest bez watpienia ustawa o działalności ubezpieczeniowej i reasekuracyjnej ${ }^{98}$, ta koncepcja pozostała w aktualnie obowiązującej ustawie, także wyrażona przez normę bezwzględnie wiążąca. Zatem zasadnicze argumenty wyrażone w stosunku do historycznych rozwiązań poprzednio obowiązujących są, oczywiście przy zachowaniu reguły kolizyjnej lex posteriori derogat legi priori, aktualne.

Przede wszystkim z tego względu należy zwrócić uwagę, że zgodnie $\mathrm{z}$ art. 10 ust. 1 u.d.u.r. powództwo o roszczenie wynikające $\mathrm{z}$ umowy ubezpieczenia można wytoczyć według przepisów o właściwości ogólnej albo przed sąd właściwy dla miejsca zamieszkania lub siedziby ubezpieczającego, ubezpieczonego bądź uprawnionego z umowy ubezpieczenia. Dodatkowo ustawodawca wprowadził rozwiązanie stanowiące novum wobec poprzedniego stanu prawnego, zgodnie z którym powództwo o roszczenie wynikające z umowy ubezpieczenia można wytoczyć według przepisów

95 Ibidem.

96 Por. J. Kukiełka: Gwarancje z punktu widzenia zakładu ubezpieczeń..., s. 30.

97 Dz.U. 2009, nr 42, poz. 341; uwagi krytyczne nt. nowelizacji: E. Kowalewski, D. Fuchs, M.P. Ziemiak: Implementacja dyrektywy reasekuracyjnej..., s. 15-41.

98 Szerzej do poprzedniego stanu prawnego D. Fuchs: Prawo ubezpieczeń komunikacyjnych. Uwagi z perspektywy akademickiej. W: Ubezpieczenia komunikacyjne OC $w$ Europie i $w$ Polsce. Aktualne problemy. Red. M. Monkiewicz. Warszawa 2009, s. 115-117. 
o właściwości ogólnej albo przed sąd właściwy dla miejsca zamieszkania spadkobiercy ubezpieczonego lub spadkobiercy uprawnionego z umowy ubezpieczenia (art. 10 ust. 2 u.d.u.r.). Tę zmianę należy przyjąć pozytywnie, chociaż wystarczyłoby przyjęcie jako kryterium właściwości ogólnej lub miejsca zamieszkania albo siedziby osoby uprawnionej do świadczenia ubezpieczeniowego. Wówczas nie byłoby potrzeby uszczegółowiania kryterium podmiotowego przez ustawodawcę, a obejmowałoby to także roszczenia ze stosunku gwarancji ubezpieczeniowej. Niezależnie od tego, nie ulega wątpliwości, że norma ta nie obejmuje in statu presenti roszczeń ani z umowy o udzielenie gwarancji ubezpieczeniowej, ani umowy gwarancji ubezpieczeniowej, to zaś jest koronnym argumentem, że także na poziomie prawa krajowego rodzimy ustawodawca przyjmuje zasadę, że wprowadzanie szczególnych norm z zakresu właściwości sądowej w odniesieniu do sporów z gwarancji ubezpieczeniowej jest aksjologicznie i gospodarczo nieuzasadnione.

Jest to szczególnie istotne z uwagi na kogentną treść normy powyższego artykułu, który zakłada właściwość sądu jedynie co do roszczeń wynikających $\mathrm{z}$ umowy ubezpieczenia (pozostawiając na marginesie kwestię np. bezpodstawnego wzbogacenia $)^{99}$.

Tym samym $\mathrm{w}$ ewentualnych innych sporach sądowych, które powstały w związku z wykonywaniem odrębnych od umowy ubezpieczenia czynności ubezpieczeniowych, wymienionych np. w art. 4 ust. 2 oraz odpowiednio w art. 7 u.d.u.r. (np. umowy reasekuracji, retrocecji czy też właśnie umowy gwarancji ubezpieczeniowej), do oceny właściwości sądu będa miały zastosowanie wyłącznie odpowiednie normy k.p.c., jak $\mathrm{w}$ acien regime. Innymi słowy, należy podkreślić raz jeszcze, że zakres przedmiotowy normy art. 10 u.d.u.r. nie obejmuje właściwości sporów ze stosunku gwarancji ubezpieczeniowej.

Podobny wniosek można byłoby prima facie wysnuć de lege lata $\mathrm{w}$ razie zawezwania do próby ugodowej (niezależnie od tego, czy zawezwanie odnosi się do roszczeń z umowy ubezpieczenia, czy - co w praktyce jest coraz częstsze - z gwarancji ubezpieczeniowej), a to przez wzgląd na dyspozycję normy zawartej w art. 185 k.p.c., co jednak częściowo jest sprzeczne z wykładnią teleologiczną zarówno art. 10 u.d.u.r., jak i art. 20 ust. 1 oraz art. 34a u.u.o.

W konsekwencji, zdaniem piszącego, o ile w przypadku zawezwania do próby ugodowej, gdzie źródłem sporu jest stosunek gwarancji ubezpieczeniowej, taki wniosek jest zarówno przez wzgląd na wykładnię językową, jak i celowościową słuszny, o tyle w przypadku umowy ubezpiecze-

${ }_{99}$ Zob. inaczej E. Bukowska, w: Ustawa o działalności ubezpieczeniowej i reasekuracyjnej. Komentarz. Red. P. Czublun. Warszawa 2016, s. 55. 
nia właśnie ta ostatnia przemawia (wraz z regułą lex specialis derogat legi generali) za odmienna interpretacją, dająca pierwszeństwo stosownej normie z ustawy o działalności ubezpieczeniowej i reasekuracyjnej. Niestety w orzecznictwie polskich sądów powszechnych reprezentatywne jest stanowisko traktujace art. 185 k.p.c. jako lex specialis nawet wobec norm szczególnych zawartych $\mathrm{w}$ prawodawstwie ubezpieczeniowym, co znajduje uzasadnienie dodatkowo w poglądach doktryny, która zazwyczaj nie rozważa przy tej okazji relacji art. 185 k.p.c. do norm ustaw szczególnych ${ }^{100}$.

Z tego powodu należy przyjąć, że ponieważ w drodze ugody sądowej dochodzi do (jeżeli oczywiście strony ja zawra) wygaszenia sporu ubezpieczeniowego i temu też celowi służy zawezwanie do próby ugodowej wnioskowane przed sądem powszechnym, wobec tego norma $\mathrm{z}$ u.d.u.r. stanowi lex specialis wobec art. 185 k.p.c., jako z natury swej odnoszacy się do wszystkich tych spraw, w których dopuszczalne jest zawarcie ugody przed sądem powszechnym. Dlatego prymat należy przyznać właściwości sądu wyznaczanej za pomoca norm zredagowanych w art. 10 u.d.u.r., jak i art. 20 ust. 1 oraz art. 34a u.u.o. Niestety, jak wyżej zasygnalizowano, nie pomaga to w sytuacji próby godzenia sporu z gwarancji ubezpieczeniowej, wówczas bowiem, wobec braku możliwości zastosowania przepisów u.d.u.r., nie ulega wątpliwości, że właściwy będzie art. 185 k.p.c.

Z tego też względu zachowuje tutaj aktualność (podobnie jak pod rzadami pierwotnie obowiązującej ustawy o działalności ubezpieczeniowej z 1990 r. ${ }^{101}$ oraz ustawy o działalności ubezpieczeniowej z 2003 r.) sentencja postanowienia Sądu Apelacyjnego w Warszawie, zapadłego w nawiązaniu do art. 94 ust. 1 ówczesnej ustawy ubezpieczeniowej, zgodnie z która, jeżeli roszczenie nie wynika z umowy ubezpieczenia łączącej strony, właściwe będą przepisy Kodeksu postępowania cywilnego ${ }^{102}$. Ponieważ tak będzie w omawianym przypadku, to powyższe można będzie aplikować do stosunku gwarancji ubezpieczeniowej. W konsekwencji podstawowe znaczenie będzie miał także art. 30 k.p.c., stwierdzający,

${ }^{100}$ Por. J. Parafianowicz, w: Kodeks postępowania cywilnego. Postępowanie procesowe. Komentarz. Red. O.M. Piaskowska. LEX [Dostęp: 4.04.2020 r.]; P. Telenga, w: Kodeks postępowania cywilnego. Komentarz. Red. A. Jakubecki. Warszawa 2019. LEX [Dostęp: 4.04.2020 r.], a także E. Stefańska, w: Kodeks postępowania cywilnego. Komentarz. T. 1. Art. 1-505(38). Red. M. Manowska. Wyd. 3. Warszawa 2015. LEX [Dostęp: 4.04.2020 r.], jak również A. Zieliński: Kodeks postępowania cywilnego. LEGALIS [Dostęp: 4.04.2020 r.].

${ }^{101}$ Ustawa z dnia 28 lipca 1990 r. o działalności ubezpieczeniowej. Dz.U. 1996, poz. 62 ze zm.

${ }^{102}$ Postanowienie SA w Warszawie z dnia 16.01.1996 r., I ACz 1350/95. „Monitor Prawniczy" 1996, nr 12, s. 461; por. także D. Fuchs, w: A. Brodecka-Chamera et al.: Prawo ubezpieczeń gospodarczych. Komentarz. T. 2.., s. 77 i n. 
że powództwo przeciwko osobie prawnej (poza Skarbem Państwa; por. art. 29 k.p.c.) lub innemu podmiotowi niebędącemu osoba fizyczną wytacza się według miejsca ich siedziby ${ }^{103}$. Będzie to adekwatne wobec braku podstaw w przypadku gwarancji ubezpieczeniowej do zastosowania art. 10 u.d.u.r. ${ }^{104}$ Wobec tego spór wprawdzie będzie miał związek z działalnością ubezpieczeniową, ale podstawą zgłaszanych roszczeń będzie nie umowa asekuracji, lecz umowa gwarancji ubezpieczeniowej, właściwość sądu będzie wyznaczana przez art. 33 k.p.c., stanowiący, że powództwo o roszczenie majątkowe przeciwko przedsiębiorcy (scil. ubezpieczycielowi, jako gwarantowi z gwarancji ubezpieczeniowej, albo też dochodzacemu od przedsiębiorcy zapłaty za udzielenie gwarancji, albo też dochodzącemu regresu wobec kontrahenta ze względu na wypłatę beneficjentowi sumy gwarancji - w tym ostatnim przypadku konieczne jest odpowiednie postanowienie umowne, nie wystarczy odwołanie się do art. 828 k.c., bo ubezpieczeniowe cessio iuris występuje tylko w związku z umową ubezpieczenia) można wytoczyć przed sąd, w którego okręgu znajduje się jednostka organizacyjna pozwanego lub jej zakład mający za zadanie prowadzenie działalności gospodarczej, jeżeli roszczenie pozostaje $\mathrm{w}$ związku z działalnością tej jednostki lub zakładu ${ }^{105}$. Analogicznie, w stosunku gwarancji ubezpieczeniowej próżno doszukiwać się, jeżeli strony tak odrębnie nie postanowia, możliwości regresowania ${ }^{106}$.

Podsumowując stanowisko rodzimej doktryny i orzecznictwa, należy zwrócić uwagę na bardzo trafne konstatacje Sądu Najwyższego zawarte w uzasadnieniu wyroku z dnia 14 lutego 2018 r., w którym stwierdzono: „gwarancja jest instytucją ukształtowaną w praktyce rynkowej w ramach zasady swobody umów (art. $353^{1}$ k.c.), mająca fragmentaryczne uregulowania głównie dotyczące gwarancji bankowej. Pod ogólnym pojęciem gwarancji występuja typowo trzy, powiązane ze sobą, stosunki prawne:

${ }^{103}$ Por. J. Gudowski, M. Jędrzejewska, w: Kodeks postępowania cywilnego. Komentarz. T. 1: Postępowanie rozpoznawcze. Red. T. Ereciński. Wyd. 5. Warszawa 2016. LEX [Dostęp: 4.04.2020 r.].

${ }^{104}$ Szerzej D. Fuchs: Jurysdykcja sqdów powszechnych w zakresie ubezpieczeń gospodarczych zgodnie z rozporzadzeniem nr 1215/2012 (tzw. Bruksela I bis)...

${ }^{105}$ Szerzej A. Zieliński: Kodeks postępowania cywilnego...; zob. M.P. Wójciuk, w: Kodeks postępowania cywilnego. Komentarz. Red. A. Jakubecki...; rozwiazanie to w niektórych prawodawstwach krajowych jest stosowane także w odniesieniu do sporów wynikajacych z umowy ubezpieczenia; por. G. Tekinalp: The 2007 Turkish code concerning private international law and international civil procedure. "Yearbook of Private International Law" 2007, vol. 9, s. 340 - odrębność występuje (scil. w przypadku prawa tureckiego), gdy pozwany przez ubezpieczyciela jest ubezpieczajacy lub beneficjent, w takim razie właściwy jest sąd jego miejsca zamieszkania albo siedziby. Ibidem.

${ }^{106}$ Co słusznie zauważa E. Kowalewski: Prawo ubezpieczeń gospodarczych..., s. 352; podobnie L. Michalik, D. Seliga: Ubezpieczenia finansowe..., s. 307. 
stosunek prawny łączący wierzyciela z dłużnikiem, z którego wynika konieczność zabezpieczenia interesów wierzyciela, wynikających z tego stosunku (tzw. stosunek podstawowy), stosunek zlecenia udzielenia gwarancji, w ramach którego dłużnik ze stosunku podstawowego zleca udzielenie gwarancji innemu podmiotowi - bankowi, zakładowi ubezpieczeń lub innemu - w celu zabezpieczenia interesów wierzyciela, oraz stosunek gwarancji pomiędzy osobą gwaranta a beneficjentem gwarancji. Już sama konstrukcja instytucji gwarancji powoduje trudności w porównywaniu jej do umowy ubezpieczenia, gdyż w istocie należałoby porównywać do tej umowy zarówno umowę zlecenia udzielenia gwarancji, jak również udzielenie samej gwarancji, a w konsekwencji porównywać pozycję i obowiązki stron umowy ubezpieczenia (ubezpieczyciela, ubezpieczającego i ubezpieczonego) do pozycji i obowiązków stron umowy zlecenia gwarancji (zlecającego gwarancję i gwaranta) oraz pozycji i obowiązków stron samej gwarancji (gwaranta i beneficjenta gwarancji). I tak beneficjent gwarancji na podstawie udzielonej mu gwarancji, w przeciwieństwie do ubezpieczonego wobec ubezpieczyciela, nie jest obarczony jakimkolwiek obowiązkiem w stosunku do osoby gwaranta. Beneficjenta gwarancji obciążaja jedynie obowiązki czysto formalne $\mathrm{w}$ razie zwrócenia się o wypłatę sumy gwarancyjnej w razie ziszczenia się warunków jej zapłaty. W odróżnieniu od umowy ubezpieczenia sam stosunek gwarancji nie polega na zapewnieniu beneficjenta, że otrzyma on równowartość poniesionej szkody ani też na tym, że gwarant nie zapłaci więcej niż wynosi szkoda beneficjenta w razie wystapienia zabezpieczonego ryzyka. Suma, która gwarant ma zapłacić beneficjentowi, jest bowiem ustalona z góry na wypadek niewystapienia gwarantowanego rezultatu. Nie jest to więc odpowiedzialność odszkodowawcza, natomiast mechanizm wypłaty sumy gwarancyjnej i przesłanki jej żądania ułatwiają zaspokojenie beneficjenta gwarancji. Sumie gwarancyjnej - stanowiącej górna granicę odpowiedzialności odszkodowawczej ubezpieczyciela - można nadać charakter gwarancyjny w oderwaniu od wysokości szkody (art. 824 k.c.), ale także wówczas nie zmienia to odszkodowawczego charakteru odpowiedzialności wynikającej z umowy ubezpieczenia. Zobowiązanie gwaranta wobec beneficjenta ma charakter samoistny. Gwarant nie może wobec tego wobec beneficjenta gwarancji powoływać się na zarzuty ze stosunku zlecenia gwarancji. Umowę ubezpieczenia, w tym na cudzy rachunek, może zawrzeć jako ubezpieczyciel wyłącznie zakład ubezpieczeń spełniający wymagania określone w odrębnej ustawie. Natomiast gwarancji mogą udzielać różne podmioty, w tym banki i zakłady ubezpieczeń. Jedynie w przypadku gwarancji ubezpieczeniowej gwarantem jest zakład ubezpieczeń. Inne są też świadczenia ubezpieczającego $\mathrm{w}$ przypadku umowy ubezpieczenia oraz zlecającego udzielenie gwarancji, w tym ubezpieczeniowej. W przypadku umowy ubez- 
pieczenia ubezpieczający obowiązany jest do zapłaty świadczenia określonego w ustawie oraz według zasad tam określonych, tj. składki obliczonej za czas trwania odpowiedzialności ubezpieczyciela (art. $805 \S 1$ k.c. oraz art. $813 \S 1$ zd. pierwsze k.c.). W przypadku wygaśnięcia stosunku ubezpieczenia przed upływem okresu, na jaki została zawarta, ubezpieczajacemu przysługuje zwrot składki za okres niewykorzystanej ochrony ubezpieczeniowej. Przepisy te maja charakter kognitywny. Natomiast w razie zawarcia umowy zlecenia udzielenia gwarancji, w tym ubezpieczeniowej — jak to zasadnie argumentował Sąd drugiej instancji — świadczenie zakładu ubezpieczeń w przypadku umowy o udzielenie gwarancji polega nie na wypłacie, ale na wystawieniu uzgodnionej gwarancji (świadczenie o charakterze niepieniężnym), a zleceniodawca gwarancji zobowiązany jest do zapłaty wynagrodzenia gwarantowi. Zasady zapłaty tego wynagrodzenia i ustalania jego wysokości nie sa poddane regulacjom prawnym, lecz podobnie jak sama instytucja gwarancji, sa kształtowane wola stron oparta na zasadzie swobody umów (art. 353 (1) k.c.). Do istotnych elementów instytucji gwarancji należy zapłata kwoty gwarancyjnej, a nie zapłata prowizji. Nie jest wyłączone udzielenie gwarancji nawet bez wynagrodzenia. Inaczej jest też określana wysokość świadczeń w postaci składki ubezpieczeniowej i prowizji za udzielenie gwarancji. W odniesieniu do pierwszego z nich o wysokości składki ubezpieczeniowej decyduje kalkulacja ryzyka wystąpienia zdarzenia ubezpieczeniowego, a w odniesieniu do drugiego z nich o jego wysokości decyduje przede wszystkim kalkulacja ryzyka refinansowania udzielonego w ten sposób kredytu. $\mathrm{O}$ ile bowiem w przypadku umowy ubezpieczenia istotne jest ryzyko wystąienia określonego zdarzenia ubezpieczeniowego, o tyle w przypadku gwarancji, w której gwarant przyjmuje ryzyko związane z realizacją bądź niepowodzeniem określonego $\mathrm{w}$ umowie przedsięwzięcia, a co się $\mathrm{z}$ tym wiąże - w razie konieczności zapłaty kwoty gwarancji — istotne jest ryzyko związane ze zwrotem wypłaconej sumy gwarancyjnej. Gwarant działa na cudzy rachunek, a zakład ubezpieczeń na rachunek własny. Zasadnie przyjął więc Sąd drugiej instancji, że w przypadku gwarancji nie następuje tak, jak to jest $\mathrm{w}$ umowie ubezpieczenia, transfer ryzyka na zakład ubezpieczeń, ponieważ dłużnik pozostaje cały czas odpowiedzialny za właściwe wykonanie przyjętego na siebie zobowiązania. [...] [W] orzecznictwie Sąu Najwyższego wyrażono stanowisko, że gwarancja ma swój własny reżim prawny i brak podstaw dla analogicznego stosowania do jej przepisów odnoszacych się do umowy ubezpieczenia (wyrok z dnia 17 grudnia 2004 r., II CK 308/04, niepubl.)"107.

${ }^{107}$ Por. wyr. SN z dnia 14.02.2018 r., sygn. CSK 270/17. OSNC-ZD, nr A, poz. 10, na który zwrócił uwagę autorowi SSN prof. M. Bączyk, podczas dyskusji na konferen- 
Na koniec rozważań należy także podkreślić rangę sporów z gwarancji ubezpieczeniowej normy interpretacyjnej zawartej w art. 11 u.d.u.r., która wpływa na właściwość sądu, ze względu na treśś art. 10 (odpowiednio art. 20 oraz 34a u.u.o.), a mianowicie: „Wskazanie w piśmie procesowym oddziału zagranicznego zakładu ubezpieczeń jako strony postępowania dotyczącego roszczenia wynikającego z działalności zagranicznego zakładu ubezpieczeń wykonywanej na terytorium Rzeczypospolitej Polskiej przez oddział jest jednoznaczne ze wskazaniem jako strony tego postępowania zagranicznego zakładu ubezpieczeń". Ma to przede wszystkim znaczenie również dla rozstrzygnięcia, czy dany spór podlega przepisom rozporządzenia Bruksela I bis, ze względu na to, że wówczas charakter sporu ubezpieczeniowego powinien być prima facie zakwalifikowany jako transgraniczny w znaczeniu prawa europejskiego.

\section{Wnioski}

Zdaniem autora, z przytoczonych wywodów wynika, zarówno na podstawie wykładni autonomicznej, jak i próby sięgnięcia do lex fori ${ }^{108}$ sekcji 3. rozporządzenia Bruksela I bis, że szczególne normy jurysdykcyjne o ubezpieczeniach nie mają zastosowania do sporów mających swe źródło w stosunku gwarancji ubezpieczeniowej. Widoczne limitowane podobieństwa pomiędzy stosunkiem prawnym gwarancji ubezpieczeniowej i umowy ubezpieczenia dotychczas zarówno nie skłoniły prawodawców krajowych to takiego „upodobnienia”, jak też nie znajduja odzwierciedlenia w głównym nurcie interpretacji norm rozporządzenia UE Bruksela I bis, co oczywiście nie wyklucza formułowania wniosków de lege ferenda. Według autora, także wykładnia celowościowa, z uwzględnieniem powyższych konstatacji odnoszących się do reasekuracji i odpowiednio retrocesji, skłania roztropnie do wykładni nakazującej do sporów ze stosunku gwarancji ubezpieczeniowej stosować normy Bruksela I bis odpowiednie do spraw z zakresu gwarancji bankowej, a nie szczególne, charakterystyczne dla sporów z umowy ubezpieczenia.

W konsekwencji w stanie obecnym, jeżeli kierować się celowościa prawodawcy unijnego, na podstawie autonomicznej wykładni pojęć użytych przez niego m.in. do ubezpieczeń gospodarczych, zdaniem autora,

cji nt. Aktualne problemy prawa prywatnego międzynarodowego, Toruń, 13-14 czerwca 2019 r.

${ }^{108}$ Zob. K. Pacuła: Kwalifikacja w prawie prywatnym międzynarodowym Unii Europejskiej... 
należy opowiedzieć się przeciwko możliwości uznania, że sekcja 3. rozporządzenia Bruksela I bis obejmuje swym zakresem przedmiotowym także stosunki z gwarancji ubezpieczeniowej, według wcześniej przedstawionego uzasadnienia. Do tego też skłania analiza prawa polskiego w relewantnym zakresie. Dlatego warto zwrócić uwagę, że w praktyce orzeczniczej sądów powszechnych może mieć znaczenie pomocnicze sięganie do uregulowania właściwości sądowej, dokonane przez ustawodawcę polskiego na gruncie u.d.u.r., z zachowaniem jako principium postulatu autonomicznej wykładni. Chociaż obserwacje praktyczne autora skłaniaja do zwrócenia uwagi także na możliwy kierunek wykładni na podstawie subsydiarnego stosowania lex fori. Nawet jednak w takim przypadku, biorac pod uwage rozwiązania przyjęte w u.d.u.r., nie będzie de lege lata podstaw od odmiennych wniosków co do zakresu przedmiotowego norm jurysdykcyjnych w odniesieniu do spraw z zakresu gwarancji ubezpieczeniowej.

Jednakże możliwy jest również wniosek, że należy, ze względu na postulat przewidywalności w praktyce sporów ubezpieczeniowych kwestii jurysdykcji (a w konsekwencji krajowej właściwości sądowej), bez konieczności sięgania po analizę dogmatyczną uznać w przyszłości, że gwarancja ubezpieczeniowa powinna być objęta zakresem przedmiotowym sekcji 3. rozporządzenia Bruksela I bis.

Jednak wówczas na gruncie rozporządzenia Bruksela I bis należałoby, zdaniem autora, dokonać stosownej modyfikacji, przynajmniej w jego art. 10, a w konsekwencji, dbając o jednolitość rozwiązań, dokonać także stosownych zmian w art. 10 polskiej u.d.u.r.

\section{Bibliografia}

Andrzejuk B., Heropolitańska I.: Gwarancje, poręczenia, awale i akredytywy standby. Warszawa 2000.

Blajer R.: Gwarancje bankowe i ubezpieczeniowe w obrocie międzynarodowym. Warszawa 1999.

Bödeker V.: Staatliche Exportkreditversicherungssysteme. Berlin-New York 1992.

Bukowska E., w: Ustawa o działalności ubezpieczeniowej i reasekuracyjnej. Komentarz. Red. P. Czublun. Warszawa 2016.

Bull H., Musger G., Pocar F.: Drugie sprawozdanie na temat krajowego prawa precedensowego dotyczqcego Konwencji z Lugano, http://bip.ms.gov. pl/Data/Files/_public/bip/lugano/raporty/lugano_raport2.pdf. 
Clarke M.: The Law of Insurance Contracts. London 1994.

Dau ses M.A.: Jednolite prawo cywilne w Europie. „Przegląd Prawa Handlowego" 2003, nr 6.

Ellis T.H.: The Single European Market and Insurance Law and Practice. London 1994.

Encyklopedia prawa bankowego. Red. W. Pyzioł. Warszawa 2000.

Ereciński T., Ciszewski J.: Międzynarodowe postępowanie cywilne. Warszawa 2000.

Flaga-Gier uszyńska K.: Konwencja o jurysdykcji krajowej i wykonalności orzeczeń $w$ sprawach cywilnych $i$ handlowych - wybrane zagadnienia. „Rejent" 2000, nr 1.

Fras M.: Umowa ubezpieczenia grupowego. Aspekty prawne. Warszawa 2015. LEX [Dostęp: 4.04.2020 r.].

Frąckowiak-Adamska A.: Europejska przestrzeń sadowa - rozważania na tle projektu reformy rozporzadzenia Bruksela I. „Europejski Przegląd Sądowy” 2012/5/16-23. LEX [Dostęp: 4.04.2020 r.].

Freeman D.J.: International Jurisdiction and the Recognition and enforcement of foreign judgements: Preaction protocol for debt claims, www.djfree man.co.uk/pubs/l-jurisd.htm, s. 5 [Dostęp: 31.03 .2020 r.].

Fuchs D.: Charakter prawny polisy ubezpieczeniowej $w$ prawie polskim a przedmiotowy zakres zastosowania Konwencji wiedeńskiej o umowach międzynarodowej sprzedaży towarów z 1980 roku. Przyczynek do wyktadni norm międzynarodowego prawa handlowego. „Rozprawy Ubezpieczeniowe” 2009 (6), nr 1.

Fuchs D.: Działalność ubezpieczeniowa w świetle Konwencji brukselskiej Lugano o jurysdykcji $i$ wykonywaniu orzeczeń $w$ sprawach cywilnych $i$ gospodarczych. „Rejent” 1999, nr 3.

Fuchs D.: Holding ubezpieczeniowy w prawodawstwie polskim oraz wspólnotowym. Zarys problematyki. W: Harmonizacja polskiego prawa gospodarczego z wymogami Unii Europejskiej. Red. B. Gnela, R. Szostak. Kraków 2001.

Fuch s D.: Interes ubezpieczeniowy w europejskim projekcie PEICL w świetle kodeksowej regulacji umowy ubezpieczenia. W: Ksiega pamiatkowa Profesora Andrzeja Kidyby. Warszawa [w druku].

Fuchs D.: Jurysdykcja sqdowa $w$ zakresie ubezpieczeń gospodarczych wedtug rozporzadzenia Rady (WE) nr 44/2001 z dnia 22 grudnia 2000 r. w sprawie jurysdykcji $i$ uznawania orzeczeń sqdowych oraz ich wykonywania $w$ sprawach cywilnych $i$ handlowych. W: A. Brodecka-Chamera et al.: Prawo ubezpieczeń gospodarczych. Komentarz. T. 2. Warszawa 2010.

Fuchs D.: Jurysdykcja sqdów powszechnych $w$ zakresie ubezpieczeń gospodarczych zgodnie z rozporzadzeniem $\mathrm{nr}$ 1215/2012 (tzw. Bruksela I bis) z uwzględnieniem konwencji Lugano II. W: Kontrakty na rynku ubezpieczeń. Red. D. Fuchs, K. Malinowska, D. Maśniak. Warszawa [w druku].

Fuchs D.: Komentarz do art. 805 k.c. W: Kontrakty na rynku ubezpieczeń. Red. D. Fuchs, K. Malinowska, D. Maśniak. Warszawa [w druku].

Fuchs D.: Komentarz do art. 820 k.c. W: Kontrakty na rynku ubezpieczeń. Red. D. Fuchs, K. Malinowska, D. Maśniak. Warszawa [w druku]. 
Fuchs D.: Normy kolizyjne w ubezpieczeniach. Próba porównania (na przykładzie rozwiazań europejskich). W: II i III filar ubezpieczeń emerytalnych. Demograficzne $i$ społeczne uwarunkowania ubezpieczeń. Red. A. Rączaszek. Katowice 1999.

Fuchs D.: Nowelizacja kodeksu cywilnego $w$ zakresie wybranych przepisów ogólnych o umowie ubezpieczenia $w$ świetle przepisów ogólnych o umowie ubezpieczenia $w$ świetle prac Project Group on a Restatement European Insurance Contract Law. „Wiadomości Ubezpieczeniowe” 2007, 7-8.

Fuchs D.: PEICL jako materialnoprawny projekt europejskiego instrumentu opcjonalnego $w$ zakresie prawa jednolitego o umowie ubezpieczenia. W: Kontrakty na rynku ubezpieczeń. Red. D. Fuchs, K. Malinowska, D. Maśniak. Warszawa [w druku].

Fuchs D.: Prawo ubezpieczeń komunikacyjnych. Uwagi z perspektywy akademickiej. W: Ubezpieczenia komunikacyjne OC $w$ Europie i w Polsce. Aktualne problemy. Red. M. Monkiewicz. Warszawa 2009.

Fuchs D.: Swoboda świadczenia usług $w$ świetle nowego prawa ubezpieczeniowego. W: Finansowe narzędzia zarzadzania zakładem ubezpieczeń. Red. T. Sangowski. Warszawa 2005.

Fuchs D.: Transgraniczna umowa. „Miesięcznik Ubezpieczeniowy” 2006, 6.

Fuchs D.: Ubezpieczenia gospodarcze $w$ świetle Konwencji rzymskiej i projektu Rozporzadzenia „Rzym II”. „Forum Dyskusyjne Ubezpieczeń i Funduszy Emerytalnych" 2005, z. 5.

Fuchs D.: Ubezpieczenia w Unii Europejskiej [Materiał powielony, Studia podyplomowe WPiA Uniwersytetu Śląskiego w Katowicach 2011].

Fuchs D.: Ujednolicenie kontraktowego prawa reasekuracyjnego $w$ skali międzynarodowej „in statu nascendi” - PRICL (Project of Reinsurance Contract Law). „Wiadomości Ubezpieczeniowe” 2019, nr 1.

Fuchs D.: Umowa ubezpieczenia. Materiaty dla IV edycji Podyplomowego Studium Prawa Cywilnego dla Sędziów Sadów Powszechnych w roku 2008/2009. Warszawa 2008.

Fuchs D.: Wtaściwość miejscowa sadu polskiego $w$ przypadku sporów z gwarancji ubezpieczeniowej. „Monitor Prawniczy” 2012, nr 11.

Fuchs D.: Właściwość sadu i właściwość prawa $w$ europejskich ubezpieczeniach gospodarczych. „Prawo Asekuracyjne” 2008, nr 2.

Fuchs D.: Zarys prawa ubezpieczeń socjalnych w Unii Europejskiej. Katowice 1997.

Fuchs D.: Znaczenie ratyfikacji przez RP Konwencji z Lugano dla właściwości sqdu w zakresie ubezpieczeń gospodarczych. W: Wymiar sprawiedliwości w Unii Europejskiej. VI Ogólnopolska Konferencja Prawnicza, Toruń 1617 listopada 2000 roku. Red. C. Mik. Torun 2001.

Gołaczyński J., Zalisko M.: Jurysdykcja krajowa szczególna w sprawach dotyczacych czynu niedozwolonego lub czynu podobnego do niedozwolonego w rozporzadzeniu nr 1215/2012. „Europejski Przegląd Sądowy” 2019, nr 4.

Gudowski J., Jędrzejewska M., w: Kodeks postępowania cywilnego. Komentarz. T. 1: Postępowanie rozpoznawcze. Red. T. Ereciński. Wyd. 5. Warszawa 2016. LEX [Dostęp: 4.04.2020 r.]. 
International Contracts. Aspects of Jurisdiction, Arbitration and Private International Law. Ed. M. Koppenol-Laforce. London 1996.

Janusz W.: Rynek światowy - na przyktadzie Lloyd's. W: Kontrakty na rynku ubezpieczeń. Red. D. Fuchs, K. Malinowska, D. Maśniak. Warszawa [w druku].

Jęksa Z.: Ubezpieczenia majątku i zysku firmy. Warszawa 1999.

Kaye P.: Civil Jurisdiction and Enforcement of Foreign Judgements. Abingdon 1987.

Kodeks postępowania cywilnego. Komentarz. T. 5: Postępowanie egzekucyjne. Red. T. Ereciński. Wyd. 5. LEX [Dostęp: 4.04.2020 r.].

Kontrakty na rynku ubezpieczeń. Red. D. Fuchs, K. Malinowska, D. Maśniak. Warszawa [w druku].

Kowalewski E.: Prawo ubezpieczeń gospodarczych. Bydgoszcz-Toruń 2002.

Kowalewski E.: Problematyka kolizyjnego prawa ubezpieczeniowego. „Państwo i Prawo" 2005, z. 2.

Kowalewski E.: Ubezpieczenia transgraniczne - aspekty prawne. „Gazeta Ubezpieczeniowa" z dnia 10.01.2006 r.

Kowalewski E., Fuchs D., Mogilski W.W., Serwach M.: Prawo ubezpieczeń gospodarczych. Toruń-Bydgoszcz 2006.

Kowalewski E., Fuchs D., Ziemiak M.P.: Implementacja dyrektywy reasekuracyjnej do polskiego porzqdku prawnego. „Prawo Asekuracyjne” 2009, nr 2.

Kropholler J.: Europäisches Zivilprozeßrecht. Kommentar zu EuGVÜ und Lugano-Übereinkommen. Heidelberg 1996.

Kropka M.: Kolizyjnoprawna regulacja umowy ubezpieczenia $w$ rozporzadzeniu Rzym I. Katowice 2010.

Kropka M.: Pojęcie umowy ubezpieczenia w świetle przepisów wspólnotowych dyrektyw ubezpieczeniowych. „Problemy Prawa Prywatnego Międzynarodowego" 2007, nr 1.

Kukiełka J.: Gwarancje z punktu widzenia zaktadu ubezpieczeń. „Przegląd Ubezpieczeń Społecznych i Gospodarczych” 1998, nr 4.

Kukiełka J.: Ubezpieczenie kredytu. Warszawa 1994.

Kukiełka J.: Ubezpieczyciel jako gwarant. „Prawo Asekuracyjne” 1995, 3.

Kukiełka J., Poniewierka D.: Ubezpieczenia finansowe. Bydgoszcz-Warszawa 2003.

Kwieciński T., Pokrzywniak J., Jrus P.: Wstrzymanie realizacji gwarancji ubezpieczeniowej lub bankowej na podstawie postanowienia sqdowego. „Wiadomości Ubezpieczeniowe” 2015, nr 2.

Layton A.: The Interpretation of the Brussels Convention by the European Court and English Courts. „Civil Law Quartely” 1992, vol. 2.

Łopuski J.: Konwencja lugańska i jej znaczenie dla praktyki ubezpieczeniowej. „Prawo Asekuracyjne” 2001, nr 2.

Łopu ski J.: Konwencja o jurysdykcji $i$ wykonywaniu orzeczeń sadowych $w$ sprawach cywilnych i handlowych (Lugano 1988) z uwzględnieniem orzecznictwa Europejskiego Trybunału Sprawiedliwości. Bydgoszcz 2001. 
Łopuski J.: Umowa ubezpieczeniowa a umowa reasekuracji $w$ orzecznictwie Europejskiego Trybunału Sprawiedliwości. W: Ubezpieczenia w gospodarce rynkowej. T. 3. Red. T. Sangowski. Bydgoszcz-Poznań 2002.

Mazurkiewicz S.: Działalność gwarancyjna zakładów ubezpieczeń. „Wiadomości Ubezpieczeniowe" 1999, 1-2.

Michalik L., Seliga D.: Ubezpieczenia finansowe. W: Podstawy ubezpieczeń. T. 2: Produkty. Red. J. Monkiewicz. Warszawa 2011.

Naderhofer S.: New Federal Law on Jurisdiction. Harmonisation of Local Jurisdiction in Civil Matters in Domestic Context, www.bscc.co.uk/taxnews/ tax0300.html [Dostęp: 31.03.2020 r.].

Pacuła K.: Kwalifikacja w prawie prywatnym międzynarodowym Unii Europejskiej. Od kwalifikacji autonomicznej ku... kwalifikacji wedtug „lex fori”. Referat wygłoszony podczas konferencji nt. Aktualne problemy prawa prywatnego międzynarodowego, Toruń, 13-14 czerwca 2019 r.

Parafianowicz J., w: Kodeks postępowania cywilnego. Postępowanie procesowe. Komentarz. Red. O.M. Piaskowska. LEX [Dostęp: 4.04.2020 r.].

Pilich M.: Statut umów ubezpieczenia wedtug rozporzadzenia Rzym I. W: Europejskie prawo procesowe cywilne $i$ kolizyjne. Red. P. Grzegorczyk, K. Weitz. Warszawa 2012.

Policha K., Wnęk A.: Prawo prywatne międzynarodowe. Zasady wyboru prawa właściwego dla dużych ryzyk ubezpieczeniowych. Zagadnienia praktyczne. „Prawo Asekuracyjne” 2011, 3.

Prawo bankowe. Komentarz. Red. E. Fojcik-Mastalska. Warszawa 1999.

Prawo o kontraktach w ubezpieczeniach. Red. Z. Brodecki. Zakamycze 2003.

Product Liability. European Laws and Practice. Ed. C. Hodges. London 1993.

Quigley C.: Zakres zastosowania konwencji brukselskiej i konwencji lugańskiej. „Kwartalnik Prawa Prywatnego” 1999, z. 4.

Renfors C., van der Velden F., Wagner R.: Trzecie sprawozdanie na temat krajowego prawa precedensowego dotyczqcego konwencji z Lugano, https:// bip.ms.gov.pl/Data/Files/_public/bip/lugano/raporty/lugano_raport3.pdf [Dostęp: 31.03.2020 r.].

Schlosser P.: Europäisches Gerichtsstands- und Vollstreckungsübereinkommen mit Luganer Übereinkommen und den Haager Übereinkommen über Zustellung und Beweisaufnahme. München 1996.

Stefańska E., w: Kodeks postępowania cywilnego. Komentarz. T. 1. Art. 1-505(38). Red. M. Manowska. Wyd. 3. Warszawa 2015. LEX [Dostęp: 4.04 .2020 r.].

Tekinalp G.: The 2007 Turkish code concerning private international law and international civil procedure. „Yearbook of Private International Law” 2007, vol. 9.

Telenga P., w: Kodeks postępowania cywilnego. Komentarz. Red. A. Jakubecki. Warszawa 2019. LEX [Dostęp: 4.04.2020 r.].

Tracz G.: Umowa gwarancji ze szczególnym uwzględnieniem gwarancji bankowej. Kraków 1998.

Trocha: Jest wreszcie nowe rozporzadzenie Bruksela I bis, http://www.codoza sady.pl/jest-wreszcie-nowe-rozporzadzenie-bruksela-i-bis/ [Dostęp: 4.05.2018 r.]. 
Trocha B.: Uwagi na tle częściowego rozszerzenia zakresu podmiotowego rozporzadzenia Bruksela I bis na pozwanych z państw trzecich. „Polski Proces Cywilny" 2013, 2. LEX [Dostęp: 4.04.2020 r.].

Tynel A., Funk J., Chwalej W.: Międzynarodowe prawo handlowe. Red. M. Pazdan. Warszawa 2002.

Ubezpieczenia finansowe i gwarancje ubezpieczeniowe. Red. R. Holly. Warszawa 2003.

Walter G., Baumgarten S.P.: Recognition and Enforcement of Foreign Judgements Outside the Scope of the Brussels and Lugano Conventions. The Hague-London-Boston 2000.

Wandt M., Gal J.: Solvency II is unexpected. Indirect regulation of the Reinsurance Contract, http://www.icir.de/fileadmin/Documents/Policy_Platform/ 180426_ICIR_JB_PP_Solvency_II_Unexpected.pdf [Dostęp: 31.03 .2020 r.].

Weitz K.: Projektowane zmiany rozporzadzenia nr 44/2001. W: Europejskie prawo procesowe cywilne $i$ kolizyjne. Red. P. Grzegorczyk, K. Weitz. Warszawa 2012.

Weitz K.: Przedmiotowy zakres zastosowania Konwencji lugańskiej. „Kwartalnik Prawa Prywatnego" 2000, z. 2.

Zieliński A.: Kodeks postępowania cywilnego. LEGALIS [Dostęp: 4.04.2020 r.]. 